\title{
Pembangunan Mahasiswa Melalui Program Tarbiah oleh Belia Harmoni di Selangor
}

\author{
Student Development Through Tarbiah \\ Programme by Belia Harmoni in Selangor \\ Fadhilatul Ehsan Fakhrul Adabi \\ Department of Da'wah and Human Development, Academy of Islamic Studies, \\ University of Malaya, 50603 Kuala Lumpur, Malaysia. fadhilatul.ehsan@gmail.com \\ Muhammed Yusof \\ Department of Da'wah and Human Development, Academy of Islamic Studies, \\ University of Malaya, 50603 Kuala Lumpur, Malaysia. my77@um.edu.my
}

DOI: https://doi.org/10.22452/usuluddin.vol48no2.4

\begin{abstract}
Student development programme is an important programme to produce students with high standard and balance in all aspect. This article will discuss about the implementation of tarbiah (development and training) programme in developing students by Belia Harmoni in Selangor. Belia Harmoni is a platform under a Non-Governmental Organisation (NGO) namely Pertubuhan IKRAM Malaysia (IKRAM) as a specific wing to carry out tarbiah programme for students. This study has used the interview technique to obtain the data. The result of this study found that there are seven tarbiah programme implemented by Belia Harmoni during the student development process; which are usrah (group of discussion circle), katibah (qiamullail), rehlah (picnic), mukhayyam (camping), daurah (lecture on a topic), muktamar (convention) and nadwah (presentation).
\end{abstract}

Keywords: development, student, Belia Harmoni, tarbiah, usrah

\begin{abstract}
Abstrak
Program pembangunan mahasiswa merupakan program yang penting untuk melahirkan mahasiswa yang berkualiti dan seimbang dalam semua aspek. Makalah ini membincangkan tentang pelaksanaan program tarbiah dalam proses pembangunan mahasiswa oleh Belia Harmoni di Selangor. Belia Harmoni merupakan wadah yang dilancarkan oleh Pertubuhan IKRAM Malaysia (IKRAM) sebagai sayap khusus untuk menggerakkan program tarbiah dalam kalangan mahasiswa. Kajian ini menggunakan kaedah temu bual bagi mendapatkan data. Hasil kajian mendapati tujuh program tarbiah yang dilaksanakan oleh Belia Harmoni dalam proses pembangunan mahasiswa iaitu usrah, katibah, rehlah, mukhayyam, daurah, mu'tamar dan nadwah.
\end{abstract}

Kata kunci: pembangunan, mahasiswa, Belia Harmoni, tarbiah, usrah 


\section{Pendahuluan}

Pemuda hari ini merupakan generasi pemimpin kepada agama, masyarakat dan negara pada masa hadapan. Menjadi satu cabaran kepada sesebuah negara untuk memastikan generasi muda mereka memiliki ciri-ciri kepimpinan yang cemerlang. Oleh itu, kewujudan persatuan mahasiswa dalam universiti berperanan untuk mahasiswa menggilap potensi diri, melatih diri menjadi pemimpin yang berwibawa dan menjadi peneraju perubahan dalam kalangan mahasiswa. Hal ini dapat dilihat melalui pelaksanaan program yang dilaksanakan untuk para mahasiswa di universiti masing-masing. ${ }^{1}$

Fenomena yang berlaku pada hari ini mendapati bahawa terdapat pelbagai jenis program yang dilaksanakan oleh persatuan mahasiswa termasuk program tarbiah. Pelaksanaan programprogram tarbiah di universiti adalah bertujuan untuk membina keperibadian mahasiswa Muslim. Hal ini dapat dilihat apabila di sesetengah universiti, terdapat beberapa kumpulan persatuan pelajar yang berbeza menganjurkan program-program tarbiah berdasarkan cara pendekatan yang berbeza. ${ }^{2}$ Belia Harmoni merupakan antara persatuan mahasiswa yang melaksanakan program tarbiah di bawah unit Jawatankuasa Pembangunan Mahasiswa IKRAM. Tujuan program tarbiah ini dilaksanakan adalah untuk membantu para mahasiswa memperbaiki diri agar menjadi muslim yang cemerlang di dunia dan akhirat, di samping membantu para mahasiswa mempersiapkan diri untuk menjadi pemimpin negara pada masa hadapan. ${ }^{3}$

\section{Metodologi Kajian}

Kajian yang dijalankan ini terbatas kepada pembangunan mahasiswa melalui program tarbiah yang dilaksanakan oleh Belia

1 Suzianah Jiffar, "Tingkatkan Ilmu Akademik, Kemahiran di Universiti”, laman sesawang Berita Harian, dicapai 29 Ogos 2019, https://www.bharian.com.my /berita/pendidikan/2019/08/601375/tingkatkan-ilmu-akademik-kemahiran-diuniversiti.

2 “Mukhayyam Daie Mahasiswa Kebangsaan 2019", laman sesawang Persatuan Kebangsaan Pelajar Islam Malaysia (PKPIM), dicapai 23 Mei 2019, https:// www.pkpim.org.my/2019/05/23/mukhayyam-daie-mahasiswa-kebangsaan-2019/.

3 Pertubuhan IKRAM Malaysia, "HARMONI '16: Membumikan Gagasan Kampus Harmoni dalam Perjuangan", laman sesawang Pertubuhan IKRAM Malaysia, dicapai 21 Disember 2016, http://ikram.org.my/berita/item/3097harmoni-16-membumikan-gagasan-kampus-harmoni-dalam-perjuangan.html. 
Harmoni Selangor di IPTA Selangor. Kajian ini dilakukan terhadap empat buah universiti awam di Negeri Selangor sahaja iaitu Universiti Kebangsaan Malaysia (UKM), Universiti Putra Malaysia (UPM), Universiti Islam Antarabangsa (UIA) Gombak dan Universiti Teknologi MARA (UiTM) Shah Alam sebagai sampel kajian. Data dan maklumat mengenai kajian ini diperolehi melalui kaedah temu bual. Pengkaji menemu bual sembilan orang informan yang terdiri daripada barisan kepimpinan Belia Harmoni Selangor selaku pemikir dan pelaksana program tarbiah.

Kajian ini adalah kajian kualitatif yang berbentuk deskriptif. Tujuan kajian berbentuk deskriptif digunakan adalah untuk menghuraikan atau menceritakan sesuatu perkara atau peristiwa yang berlaku semasa kajian dilakukan. Kajian berbentuk deskriptif juga dilaksanakan untuk memberi penerangan yang sistematik mengenai fakta dan ciri-ciri sesuatu populasi secara tepat. ${ }^{4}$ Dalam kajian ini, diterangkan mengenai pelaksanaan program tarbiah dalam proses pembangunan mahasiswa oleh Belia Harmoni di Selangor.

\section{Pengenalan Belia Harmoni}

Belia Harmoni merupakan wadah yang dilancarkan oleh Pertubuhan IKRAM Malaysia (IKRAM) sebagai sayap khusus menangani dan menggerakkan aktiviti dalam kalangan mahasiswa. Walau bagaimanapun, nama lama bagi Belia Harmoni ialah IKRAM Siswa. ${ }^{5}$ IKRAM Siswa merupakan satu organisasi dakwah bukan kerajaan (NGO) yang ditubuhkan untuk melaksanakan program dan aktiviti dakwah dalam kalangan mahasiswa. ${ }^{6}$ IKRAM Siswa Nasional telah dilancarkan pada 19 Januari 2013 di Dewan Pro Canselor Unisel, Shah Alam, Selangor. ${ }^{7}$ Wadah yang

4 Sidek Mohd Noah, Reka Bentuk Penyelidikan: Falsafah, Teori dan Praktis (Selangor: Universiti Putra Malaysia, 2002), 42.

5 Pertubuhan IKRAM Malaysia, "Pelancaran IKRAM Siswa Bawa Sinar Buat Generasi Baru", laman sesawang Pertubuhan IKRAM Malaysia, dicapai 16 Januari 2013, http://www.ikram.org.my/berita/item/798-pelancaran-ikramsiswa-bawa-sinar-buat-generasi-baru.html

6 Ikram Siswa Nasional, "Pengenalan IKRAM SISWA", laman sesawang IKRAM SISWA Nasional, dicapai 24 Disember 2013, https://ikramsiswa nasional.wordpress.com/2012/12/24/pelancaran-ikram-siswa/

7 IKRAM Siswa Nasional, "Menghitung Hari", laman sesawang Wordpress, dicapai 5 Januari 2013, https://ikramsiswanasional.wordpress.com/2013/01/05 /menghitung-hari/. 
dinamakan IKRAM Siswa ini telah dilancarkan oleh Presiden IKRAM, Mohd Parid Syeikh Ahmad. Tujuan utama penubuhan IKRAM Siswa adalah untuk menggembleng keupayaan dan kemampuan mahasiswa sebagai bakal pemimpin untuk membina negara yang bermatlamatkan mencari keredaan Allah. ${ }^{8}$

Pada pagi 19 Januari 2013, telah diadakan mesyuarat penubuhan dan pelantikan barisan kepimpinan IKRAM Siswa yang pertama. ${ }^{9}$ Mesyuarat tersebut telah dihadiri oleh wakil-wakil 23 IKRAM Siswa IPT seluruh negara. Tujuan mesyuarat penubuhan diadakan adalah untuk memilih barisan kepimpinan baru yang sesuai untuk mencorakkan gerak kerja mahasiswa akan datang. Hasil mesyuarat telah bersepakat melantik Tuan Muhd Taufik Tuan Hussin sebagai Presiden IKRAM Siswa yang pertama. ${ }^{10}$

Pada tahun 2015, IKRAM Siswa telah mengadakan satu konvensyen yang mengumpulkan semua ahli IKRAM Siswa seluruh negara iaitu Konvensyen Mahasiswa Harmoni (HARMONI 15). HARMONI 15 merupakan konvensyen pertama yang diadakan oleh IKRAM Siswa hasil kerjasama dengan Jawatankuasa Pembangunan Mahasiswa (JKPM) IKRAM dan Asean Young Leaders Forum (AYLF).

Pada 3 Disember 2016, IKRAM Siswa telah menganjurkan Konvensyen Mahasiswa Harmoni (HARMONI 16) di TSR Conference Hall. Tema yang dibawa ke dalam konvensyen HARMONI 16 ialah "Membumikan Gagasan Kampus Harmoni Dalam Perjuangan". Dalam konvensyen HARMONI 16, IKRAM Siswa yang telah ditubuhkan pada 2013 telah bertukar nama kepada wadah baru iaitu Persatuan Belia Harmoni Malaysia (HARMONI)

8 Pertubuhan IKRAM Malaysia, "Pelancaran IKRAM Siswa Bawa Sinar Buat Generasi Baru", laman sesawang Pertubuhan IKRAM Malaysia, dicapai 16 Januari 2013, http://www.ikram.org.my/berita/item/798-pelancaran-ikramsiswa-bawa-sinar-buat-generasi-baru.html.

9 Arshad Ahmad, "Bicara IKRAM Siswa", laman sesawang Hidup Suatu Pendakian, di capai 22 Januari 2013, https://arshadahmad.wordpress.com/2013 /01/22/bicara-ikram-siswa/.

10 Pertubuhan IKRAM Malaysia, "Pelancaran IKRAM Siswa Bawa Sinar Buat Generasi Baru", laman sesawang Pertubuhan IKRAM Malaysia, dicapai 16 Januari 2013, http://www.ikram.org.my/berita/item/798-pelancaran-ikramsiswa-bawa-sinar-buat-generasi-baru.html. 
bagi merealisasikan matlamat organisasi utama iaitu "Membumikan Gagasan Kampus Harmoni dalam Perjuangan". ${ }^{11}$

Pendaftaran HARMONI telah diterima oleh Kementerian Belia dan Sukan (KBS) pada Mei 2016. Proses penubuhan telah bermula dari peringkat cawangan, daerah, negeri dan pusat di bawah pimpinan Muhammad Fikri Ahmad sebagai Pengerusi Jawatankuasa Penaja Harmoni Pusat. Objektif utama penubuhan HARMONI adalah untuk membahasakan perjuangan gagasan kampus harmoni dengan lebih mendalam agar dapat diterapkan dengan sebaik-baiknya dalam perjuangan mahasiswa. ${ }^{12}$

Pada 27 Oktober 2018, Konvensyen Mahasiswa Harmoni (HARMONI 18) telah diadakan di Pusat Konvensyen Bank Rakyat, Kuala Lumpur. Tema konvensyen HARMONI 18 ialah "Menerajui Universiti Baharu, Mencorak Kampus Harmoni". Objektif HARMONI 18 lebih kepada pembinaan ketokohan mahasiswa dalam meningkatkan kesedaran dalam diri mahasiswa terhadap isu kemanusiaan dan menjadi jurubicara dalam menyuarakan pendapat mahasiswa. $^{13}$

Akhirnya, Persatuan Belia Harmoni Malaysia telah rasmi ditubuhkan di bawah Pendaftar Pertubuhan Belia (ROY), Kementerian Belia dan Sukan (KBS) ${ }^{14}$ pada 21 Februari 2019. Tujuan pendaftaran secara rasmi ini secara ringkasnya bertujuan untuk menjadikan Persatuan Belia Harmoni Malaysia sebagai persatuan mahasiswa berdaftar dan secara langsung dapat

11 Pertubuhan IKRAM Malaysia, "HARMONI '16: Membumikan Gagasan Kampus Harmoni Dalam Perjuangan", laman sesawang Pertubuhan IKRAM Malaysia, dicapai 21 Disember 2016, http://ikram.org.my/berita/item/3097harmoni-16-membumikan-gagasan-kampus-harmoni-dalam-perjuangan.html.

12 Pertubuhan IKRAM Malaysia, "HARMONI '16: Membumikan Gagasan Kampus Harmoni Dalam Perjuangan", laman sesawang Pertubuhan IKRAM Malaysia, dicapai 21 Disember 2016, http://ikram.org.my/berita/item/3097harmoni-16-membumikan-gagasan-kampus-harmoni-dalam-perjuangan.html.

13 Pertubuhan IKRAM Malaysia, "Reformasi IPT: Belia Harmoni Sedia Bekerjasama", laman sesawang Pertubuhan IKRAM Malaysia, dicapai 29 Oktober 2018, http://www.ikram.org.my/berita/item/3569-reformasi-ipt-beliaharmoni-sedia-bekerjasama.html.

14 Pejabat Pendaftar Pertubuhan Belia, "Kunjungan Hormat Barisan Kepimpinan Baru Persatuan Belia Harmoni Malaysia", laman sesawang Laman Web Rasmi Pejabat Pendaftar Pertubuhan Belia, Kementerian Belia dan Sukan Malaysia, dicapai 7 Mac 2019, http://roy.kbs.gov.my/en/berita/kunjung-hormat-jcimalaysia-ke-atas-pejabat-pendaftar-pertubuhan-belia-malaysia-61. 
memudahkan urusan gerak kerja Persatuan Belia Harmoni Malaysia dalam universiti-universiti di Malaysia. ${ }^{15}$

\section{Konsep Tarbiah dalam Pembangunan Mahasiswa}

Perkataan tarbiah dalam Kamus Dewan bermaksud mendidik dan mengasuh ${ }^{16}$ manakala maksud perkataan tarbiah menurut al-Ikhwān al-Muslimūn ialah proses mempersiapkan manusia dengan persiapan yang menyentuh seluruh aspek kehidupan manusia supaya seimbang dunia dan akhirat. ${ }^{17}$ Tarbiah juga dikenali sebagai satu proses pembentukan peribadi Muslim secara menyeluruh. ${ }^{18}$ Proses tersebut merupakan proses meningkatkan dan memelihara iman manusia bagi menghasilkan individu Muslim yang beramal soleh serta menjadi pendakwah yang qudwah. ${ }^{19}$ Tambahan pula, tarbiah merupakan terapi ataupun ubat kepada seorang pendakwah untuk mendapatkan kekuatan dalam melakukan ibadah dan kerjakerja dakwah. Apabila seorang pendakwah didapati lesu dalam melaksanakan ibadah dan dakwah, ia merupakan tanda-tanda komitmen tarbiah pendakwah tersebut sedang lemah dan perlu melalui proses tarbiah untuk meningkatkan semula tenaga, roh dan semangat bagi melaksanakan kerja-kerja dakwah. ${ }^{20}$

Program tarbiah dapat dilihat melalui objektif program tarbiah itu sendiri. Menurut Ummu Hamzah, objektif program tarbiah adalah untuk melahirkan individu yang memiliki kefahaman tentang dasar-dasar prinsip Islam yang tidak dicemari oleh unsurunsur syirik secara amnya dan menghasilkan individu yang mempunyai ciri-ciri peribadi Muslim secara khususnya. ${ }^{21}$

15 Persatuan Belia Harmoni Malaysia, "Pendaftaran Persatuan Belia Harmoni Malaysia di Bawah Pendaftar Pertubuhan Belia (ROY)", laman sesawang Facebook, dicapai 4 Mac 2019, https://ms-my.facebook.com/beliaharmoni malaysia/posts/1262739743893585.

16 Kamus Dewan Edisi Ketiga (Kuala Lumpur: Dewan Bahasa dan Pustaka, 2002), 1376, entri "tarbiah".

17 Ali Abdul Halim Mahmus, Perangkat-perangkat Tarbiah Ikhwanul Muslimin, terj. Wahid Ahmadi, Fakhruddin Nursyam, dan Khozin Abu Faqih (Solo: Era Intermedia, 2009), 25.

18 Ummu Hamzah, “Apa Yang Kamu Mahu daripada Tarbiah?”, JOM!, Jun 2012, 67.

19 Apri Rohmainy, “Tarbiah Bukan Segala-galanya,” JOM!, Jun 2013, 95.

20 Nur Aisyah Zainordin, “Tarbiah Itu Seharusnya Menggerakkan!” JOM!, April 2012, 43 .

21 Ummu Hamzah, “Tarbiah Berteraskan Matlamat,” JOM!, September 2012, 43. 
Berdasarkan konsep tarbiah tersebut, program-program tarbiah yang dilaksanakan perlu mencapai objektif am dan khusus yang dinyatakan. Walau bagaimanapun, Hasan al-Banna menjelaskan secara terperinci mengenai ciri-ciri peribadi Muslim yang terhasil melalui proses tarbiah. Beliau mengkategorikan ciri-ciri tersebut kepada 10 ciri-ciri yang dikenali sebagai Muwasofat Tarbiah iaitu; kefahaman akidah yang lurus, amal ibadah yang benar, akhlak yang kuat, mampu bekerja, berpengetahuan luas, sihat dan kuat tubuh badan, mampu mengawal diri, teratur dalam urusan harian, menjaga masa dan bermanfaat kepada orang lain. ${ }^{22}$

Oleh itu, proses tarbiah ini perlu diterapkan ke dalam manamana bentuk program tarbiah mahasiswa untuk meningkatkan kualiti pembangunan mahasiswa itu sendiri. Melalui programprogram tarbiah yang dilakukan, dapat menghasilkan mahasiswa yang berkualiti dan menjadi aset serta harapan kepada masa depan agama dan negara.

\section{Bentuk Program Tarbiah dalam Pembangunan Mahasiswa oleh Belia Harmoni}

Pembangunan mahasiswa bertujuan untuk membina kehidupan mahasiswa di dunia ini dengan bimbingan dan kebaikan. Sementara untuk kehidupan akhirat pula adalah bertujuan untuk mendapat keredaan Allah SWT dan membawa kepada ganjaran pahala daripada Allah SWT. ${ }^{23} \mathrm{Hal}$ ini juga selari dengan tujuan penciptaan manusia mengikut acuan Islam iaitu beribadah kepada Allah, menjadi pemimpin di muka bumi, saling berkenal-kenalan sesama manusia, menegakkan syariat Allah di atas muka bumi ini dan melaksanakan undang-undang mengikut syariat Allah. ${ }^{24}$

Menurut Ali Abdul Halim Mahmud lagi, beliau menyenaraikan tujuh buah program yang sesuai bagi mahasiswa iaitu usrah, katibah, rehlah, mukhayyam, daurah, mu'tamar dan nadwah. Ketujuh-tujuh program tarbiah tersebut turut dilaksanakan oleh Persatuan Belia Harmoni Malaysia. Cara pelaksanaan ketujuh-

22 Hasan al-Banna, Majmū 'āh al-Rasāil (Iskandariah: Dār al-Da'wah, 2002), 375.

23 'Al̄̄ 'Abd al-Halīm Maḥmūd, Wasā'il al-tarbiyah 'inda al-Ikhwān al-Muslimin: Dirāsah Taḥlīliyyah Tārīkhiyah (Mīdān Sayyidah Zaynab: Dār al-Tawzi‘ wa alNashr al-Islāmiyyah, 1997), 17.

24 'Alī 'Abd al-Ḥalīm Maḥmūd, Wasā'il al-Tarbiyah 'inda al-Ikhwān alMuslimin: Dirāsah Tahlīliyyah Tārīkhiyah, 17-19. 
tujuh program tarbiah tersebut yang dilaksanakan dalam universitiuniversiti awam di Selangor hampir sama. Namun begitu, hasil kajian mendapati bahawa terdapat perbezaan dari segi jenis dan objektif program yang dilaksanakan, iaitu:

\section{Usrah}

Maksud usrah dalam konsep al-Ikhwān al-Muslimūn ialah pembinaan institusi keluarga yang kukuh kepada ahli-ahlinya serta menghasilkan pembentukan sahsiah ahli yang mantap secara menyeluruh. Ia juga merupakan asas kepada pembinaan seorang individu yang merangkumi sistem tarbiah secara menyeluruh dengan menguruskan aspek-aspek utama dalam diri seseorang iaitu akal, hati dan jasad. Dalam usrah, perkara pertama yang perlu diberi penekanan oleh setiap ahli ialah membina ikatan hati. Pembinaan ikatan hati ini akan menghasilkan kekuatan ukhuwah sesama ahli yang membuatkan seseorang ahli itu sanggup berkorban atau membantu apa sahaja demi saudara sesama Muslim. Walau bagaimanapun, usrah merupakan asas utama kepada pembinaan sebuah organisasi. ${ }^{25}$

Kajian juga mendapati antara objektif program usrah yang dilakukan oleh Belia Harmoni di IPTA Selangor adalah untuk membina keperibadian Muslim dalam diri mahasiswa dan memperbaiki diri mahasiswa menjadi yang lebih baik. Selain itu, objektif terpenting dalam program usrah adalah untuk mengeratkan ukhuwah sesama ahli usrah. Objektif yang ditetapkan oleh Belia Harmoni ini bertepatan dengan apa yang telah digariskan oleh alIkhwān al-Muslimūn. Dengan adanya kekuatan ukhuwah ini, program usrah yang dilaksanakan menjadi asas kekuatan kepada 'amal jama' $\bar{\imath}$ (kerja kolektif) terutama bagi Persatuan Belia Harmoni. Objektif-objektif tersebut telah dinyatakan oleh para informan yang telah ditemubual.

Menurut Siti Hajar, objektif pelaksanaan usrah ini adalah untuk memperbaiki diri setiap ahli usrah kepada yang lebih baik. Beliau juga menyatakan,

Target kita bagi setiap ahli yang mengikuti usrah adalah untuk membina 10 Muwasaffat Tarbiyah seperti yang telah dianjurkan oleh Imam Hasan al-Banna ke dalam diri mereka. Selain itu juga, usrah ini kita jadikan dia sebagai core utama

25 Ḥasan al-Banna, Majmū 'ah al-Rasā' 'il, 286. 
dalam mentarbiah individu kerana ia merupakan medium yang paling berkesan dan sangat membantu para naqibah untuk fokus membina mutarabbi masing-masing. ${ }^{26}$

Nur Zakiah Najihah menyatakan bahawa program usrah yang dilaksanakan ini adalah untuk mengeratkan ukhuwah sesama ahli. Hal ini turut dinyatakan oleh Hasan al-Banna mengenai elemen utama yang perlu ada dalam program usrah. Dalam program usrah, setiap ahli berpeluang untuk mengenali, memahami dan membantu sesama ahli usrah. Perkara ini penting kerana ia dapat menerapkan kefahaman sesama ahli untuk melaksanakan gerak kerja dakwah dalam kelompok yang lebih kecil dan berfokus. ${ }^{27}$

Bagi Aliyah, di samping membina dan membentuk keperibadian, usrah juga turut dilaksanakan untuk membina fikrah Islam seperti yang dilaksanakan oleh al-Ikhwān al-Muslimūn. Dalam usrah berlaku proses memindahkan fikrah dari seorang naqibah kepada mutarabbinya melalui perbincangan mengenai tafsir Al-Qur'an, hadith, sirah dan buku-buku fikrah. Hal ini turut dinyatakan oleh Farīd 'Abd al-Khāliq bahawa dalam usrah perlu diberi penekanan kepada setiap ahli untuk sentiasa meningkatkan kualiti bacaan dan hafalan al-Quran kepada yang lebih baik. ${ }^{28}$ Aliyah menyatakan lagi,

Proses pemindahan fikrah ini sangat penting dalam tarbiah kita kerana setiap mutarabbi yang kita bina sekarang merupakan bakal murabbi kepada orang lain pula pada masa akan datang. Jadi pemahaman fikrah yang betul dan benar ini sangat penting untuk kita tanamkan kepada mereka supaya mereka juga boleh menyampaikan fikrah kita ini kepada orang lain kelak. ${ }^{29}$

Dapat kajian mengenai objektif usrah yang dinyatakan oleh para informan hampir sama dari aspek pemantapan ukhuwah dan perubahan individu kepada yang lebih baik. Namun, tajuk pengisian

26 Siti Hajar Binti Mohammad (Jawatankuasa Pembangunan Mahasiswa (JKPM) IKRAM Bangi), dalam temubual dengan pengkaji, 5 Oktober 2018.

27 Nur Zakiah Najihah Binti Bahar (Ahli Jawatankuasa (AJK) Belia Harmoni Universiti Kebangsaan Malaysia, Bangi), dalam temubual dengan pengkaji, 26 Oktober 2018.

28 Farīd 'Abd al-Khāliq, Al-Ikhwān al-Muslimūn fì Mīzān al-Haq (Kaherah: Dār al-Ṣahwah li al-Nashr, 1987), 191.

29 Aliyah Ahmad Bahari (Jawatankuasa PembangunanMahasiswa (JKPM) Universiti Islam Antarabangsa, Gombak), dalam temubual dengan pengkaji, 27 Oktober 2018. 
yang disampaikan di dalam usrah adalah berbeza mengikut keperluan ahli usrah.

Bentuk pelaksanaan program usrah ini, kebiasaannya dimulai dengan bacaan tilawah al-Qur'an yang bersesuaian dengan tema usrah pada waktu itu. Selesai membaca al-Qur'an, naqib atau naqibah usrah (pemimpin usrah) akan memberi kata-kata pembukaan dan mengajak ahli usrah untuk menyediakan diri masing-masing untuk menerima input dalam usrah. Kemudian, usrah diteruskan dengan sesi pembelajaran silibus usrah sama ada dari kitab tafsir, hadith ataupun sirah untuk dibincangkan dan difikirkan bersama-sama bagi memastikan setiap ahli usrah jelas dengan perbincangan yang berlaku. Selesai perbincangan silibus usrah, naqib dan naqibah akan bertanya kepada mutarabbi mengenai perihal dan kondisi mutarabbi masing-masing. Naqib atau naqibah akan bertanya kepada mutarabbi masing-masing "adakah mereka mempunyai masalah?" atau "adakah mereka ingin mengkongsikan berita-berita gembira kepada ahli usrah?". Hal ini secara tidak langsung dapat mengeratkan ukhuwah antara ahli usrah, membina kepercayaan kepada ahli usrah serta membantu mana-mana ahli usrah yang memerlukan bantuan. ${ }^{30}$

Bagi pelaksanaan usrah di UKM, Nur Zakiah Najihah mengatakan bahawa usrah diketuai oleh seorang naqibah. Dalam usrah akan berlaku perbincangan mengenai silibus atau modul dalam kalangan ahli usrah mengenai Tafsir Al-Azhar, Majmü 'ah Rasā'il, Fiqh Sirrah dan modul-modul lain mengikut keadaan dan keperluan semasa. Beliau juga menyatakan;

Setiap kali usrah juga, naqibah akan mempersiapkan diri dengan membaca dan mencari maklumat-maklumat tambahan yang bersesuaian dengan topik perbincangan untuk disampaikan dan dibentangkan kepada ahli usrah. ${ }^{31}$

Menurut A'aisyah Mardhiyyah pula, usrah akan dimulai dengan tilawah dan tadabbur ayat-ayat al-Qur'an. Kemudian, berlaku sesi perbincangan mengenai tafsir juzuk 29 dan 30 yang diketuai oleh naqibah. Di samping itu juga, setiap ahli usrah saling

30 'Alī 'Abd al-Halīm Maḥmūd, Wasā'il al-Tarbiyah 'inda al-Ikhwān alMuslimin: Dirāsah Tahlīliyyah Tārīkhiyah, 170-171.

31 Nur Zakiah Najihah Bahar (Ahli Jawatankuasa (AJK) Belia Harmoni Universiti Kebangsaan Malaysia, Bangi), dalam temubual dengan pengkaji, 26 Oktober 2018. 
menceritakan perihal atau keadaan semasa diri masing-masing untuk dikongsikan bersama naqibah dan ahli usrah yang lain. ${ }^{32}$

Siti Saripa Rabiah menjelaskan bahawa usrah ini terbentuk daripada seorang naqibah dan beberapa orang mutarabbi dalam jumlah yang kecil. Segala perbincangan fikrah dan ilmiah secara teori diterapkan dan diamalkan dalam kehidupan seharian. Kemudian naqibah akan follow up bagi memastikan setiap mutarrabi melaksanakan amal-amal yang sepatutnya dilakukan oleh seorang muslim. Beliau menyatakan;

Kebiasaannya, naqibah akan follow up melalui whatsapp group usrah untuk update mutaba'ah amal masing-masing. Melihat ahli usrah berlumba-lumba update mutaba'ah amal masing-masing, secara tidak langsung ia dapat encourage ahli usrah lain untuk turut update mutabaah mereka sendiri. ${ }^{33}$

Di UIA Gombak juga melaksanakan usrah hampir sama seperti yang dilaksanakan di UKM dan UPM. Aliyah menjelaskan bahawa usrah di UIA kebiasaannya memfokuskan kepada tilawah dan tadabbur al-Quran, tafsir al-Quran dan hadith serta membincangkan mengenai sirah Rasulullah SAW. Usrah biasanya dilakukan sekali seminggu. UIA Gombak menyasarkan bahawa setiap ahli Belia Harmoni perlu menghadiri 14 kali usrah bagi setiap satu semester. ${ }^{34}$

Menurut Nusaibah, pelaksanaan usrah di UIA boleh dilaksanakan dalam keadaan formal ataupun tidak formal. Kebiasaanya, usrah yang dilaksanakan secara formal membincangkan modul-modul usrah seperti tafsir, hadith dan sirah manakala pelaksanaan usrah secara tidak formal biasanya lebih santai dan dilakukan secara indoor mahupun outdoor. Nusaibah menyatakan lagi'

Usrah secara indoor kami biasa buat di kolej salah seorang ahli usrah ataupun di tempat-tempat yang bersesuaian. Manakala

32 A'aisyah Mardhiyyah Mohammad Shahini (Ahli Jawatankuasa (AJK) Belia Harmoni Universiti Putra Malaysia), dalam temubual dengan pengkaji, 23 Oktober 2018.

33 Siti Saripa Rabiah Mat Lazim (Ahli Jawatankuasa (AJK) Belia Harmoni Universiti Putra Malaysia), dalam temubual dengan pengkaji, 22 Oktober 2018.

34 Aliyah Ahmad Bahari (Jawatankuasa PembangunanMahasiswa (JKPM) Universiti Islam Antarabangsa, Gombak), dalam temubual dengan pengkaji, 27 Oktober 2018. 
usrah secara outdoor pula akan dibuat di kawasan rekreasi atau kawasan lapang. ${ }^{35}$

Tentang aspek pelaksanaan program usrah di semua IPTA di Selangor, kajian mendapati bahawa program usrah yang dilakukan hampir sama pelaksanaannya. Hal ini kerana Belia Harmoni di IPTA Selangor melalui latihan pengurusan usrah yang sama dianjurkan oleh IKRAM kawasan masing-masing. Semua usrah dipimpin oleh seorang naqib atau naqibah untuk mentarbiah beberapa orang mutarabbi. Naqib atau naqibah merupakan ketua usrah yang bertanggungjawab untuk memastikan segala objektif usrah dicapai oleh mutarabbi. Program usrah juga merupakan satusatunya program yang dilaksanakan seminggu sekali. Sebagai wasilah teras kepada Persatuan Belia Harmoni, program usrah yang dilakukan seminggu sekali ini bertujuan untuk para naqib/naqibah memastikan mutarabbi masing-masing sentiasa dalam keadaan bersedia untuk ditarbiah dan mengeratkan lagi ikatan hati sesama ahli usrah.

\section{Katibah}

Katibah berasal dari kata dasar kataba yang bermaksud gabungan sesuatu benda dengan benda yang lain. Daripada perkataan dasar tersebut menghasilkan perkataan kitāb yang bermaksud buku dan kitābah yang bermaksud tulisan, ${ }^{36}$ manakala maksud perkataan katībah ialah sepasukan tentera berdasarkan peristiwa Tsaqifah. ${ }^{37}$

Menurut organisasi dakwah al-Ikhwān al-Muslimūn, katibah didefinisikan sebagai satu program khas untuk pembangunan ahli organisasi tersebut. Program ini adalah untuk mendidik ahli supaya berdisiplin dalam pembinaan jiwa yang dapat mendekatkan diri kepada Allah SWT, melembutkan hati dan menyucikan jiwa serta mempersiapkan diri untuk beribadah kepada Allah dalam melakukan solat tahajud sambil memikirkan kekuasaan Allah. ${ }^{38}$

35 Nusaibah Mohammad (Ahli Jawatankuasa Belia Harmoni Universiti Islam Antarabangsa, Gombak), dalam temubual dengan pengkaji, 27 Oktober 2018.

${ }^{36}$ Ibn Fāris al-Qazwīn̄i, Mu 'jam Maqāyis al-Lughah (Kaherah: Muṣṭafā al-Bābī al-Halabī, 1969), 158

37 'Alī 'Abd al-Ḥalīm Mạ̣mūd, Wasā'il al-Tarbiyah 'inda al-Ikhwān alMuslimin: Dirāsah Taḥlīliyyah Tārīkhiyah, 219.

38 'Alī 'Abd al-Ḥalīm Maḥmūd, Wasā'il al-Tarbiyah 'inda al-Ikhwān alMuslimin: Dirāsah Tahlīliyyah Tārīkhiyah, 177. 
Katibah juga merupakan salah satu program pembangunan mahasiswa. Program ini bertujuan untuk menyempurnakan lagi proses pembangunan mahasiswa dengan membentuk individu untuk mendekatkan diri kepada Allah dan membina sifat perjuangan dalam diri yang bermula daripada perjuangan melawan hawa nafsu. ${ }^{39}$

Menurut Nur Zakiah Najihah, tujuan program katibah diadakan adalah untuk memupuk dan menerapkan elemen tarbiah dhātiyah (kendiri) dalam diri setiap peserta. Beliau menyatakan, Biasanya program katibah di UKM kita panggil mabit yang bermaksud bermalam. Program mabit dilaksanakan bertujuan untuk meningkatkan nilai rabbaniyyah (ketuhanan) ke dalam diri setiap ahli. Tingkatkan hubungan kita dengan Allah dengan melakukan ibadah-ibadah sunat. Mungkin ada dari kalangan ahli kita yang belum biasa melakukan qiamullail, jadi program mabit ini boleh dijadikan sebagai titik tolak kepada mereka untuk melazimi amalan qiamullail ke dalam kehidupan mereka. ${ }^{40}$

Siti Saripa Rabiah menjelaskan bahawa program katibah ini juga adalah untuk mendidik jiwa dan menyucikan hati agar perjuangan dakwah dan tarbiah yang dilaksanakan ini tidak tersasar dari kebenaran Islam. Beliau menyatakan lagi;

Setiap manusia akan sentiasa diuji imannya termasuklah para pendakwah. Penyakit-penyakit hati seperti riak, takbur, dengki dan sebagainya kadang-kadang kita sebagai pendakwah tidak boleh lari daripada perasaan-perasaan tersebut. Oleh itu, kita sangat memerlukan kekuatan rohani bagi melawan perasaanperasaan negatif yang boleh menjadi punca kepada kerosakan hati dalam menyampaikan Islam. Jadi, dalam program katibah ini, kita sama-sama diberi peringatan dan bermuhasabah diri untuk sentiasa menyucikan hati kita. ${ }^{41}$

39 Muhammad 'Abd Qādir Abū Fāris, Manhaj Taghȳ̄r 'indā alShahīdayn Hasan al-Banna wa Sayyid Quṭ (Amman, Jordan: Dār Ammār, 1997), 34.

40 Nur Zakiah Najihah Bahar (Ahli Jawatankuasa (AJK) Belia Harmoni Universiti Kebangsaan Malaysia, Bangi), dalam temubual dengan pengkaji, 26 Oktober 2018.

41 Siti Saripa Rabiah Mat Lazim (Ahli Jawatankuasa (AJK) Belia Harmoni Universiti Putra Malaysia), dalam temubual dengan pengkaji, 22 Oktober 2018. 
Menurut Aliyah, antara tujuan program katibah ini dilakukan adalah untuk memaknai sendiri erti pengorbanan diri untuk agama seperti mengorbankan masa, tenaga, jiwa, harta dan segala-galanya untuk perjuangan Islam. Beliau menyatakan lagi;

Bukan semua orang boleh tinggalkan keselesaan yang sedia ada di rumah mereka untuk bermalam beramai-ramai di satu tempat yang mereka tidak biasa. Jadi program katibah ini merupakan salah satu latihan amali untuk kita semua yang menyatakan bahawa kita sanggup berkorban untuk Islam dengan meninggalkan comfort zone kita buat sementara waktu. $^{42}$

Di samping melakukan penyucian diri dan melembutkan jiwa dan membiasakan ahli-ahli Belia Harmoni dengan ibadah-ibadah sunat, Nusaibah menyatakan bahawa objektif khusus program katibah adalah untuk membiasakan diri dengan aspek ketaatan dan keterlibatan setiap ahli ke dalam semua program yang telah ditetapkan oleh jemaah. Dalam program katibah, setiap ahli dilatih untuk menepati masa dalam setiap tindakan seperti hadir program pada waktunya, waktu makan pada masa yang perlu, waktu tidur dan bangun tidur juga pada waktu yang telah ditetapkan. ${ }^{43}$

Menurut Illani, program katibah bertujuan untuk membina diri dalam aspek kerohanian dan jihad. Beliau menyatakan lagi bahawa dengan adanya program katibah ini, setiap ahli dapat menghayati makna mujahadah secara praktikal. Hal ini kerana tidak ada satu kejayaan yang mudah dicapai melainkan dengan cara mujahadah dan jihad. Jadi, program katibah ini merupakan medium untuk melatih para ahli bermujahadah untuk mengorbankan keselesaankeselesaan yang dimiliki sebelum ini dengan menghadiri program katibah yang menghimpunkan ramai orang dalam satu tempat. ${ }^{44}$

Pandangan secara umum terhadap objektif program katibah di IPTA Selangor yang dilaksanakan oleh Belia Harmoni adalah untuk tazkiyah al-nafs (penyucian jiwa). Dalam proses pembangunan

42 Aliyah Ahmad Bahari (Jawatankuasa PembangunanMahasiswa (JKPM) Universiti Islam Antarabangsa, Gombak), dalam temubual dengan pengkaji, 27 Oktober 2018.

43 Nusaibah Mohammad (Ahli Jawatankuasa Belia Harmoni Universiti Islam Antarabangsa, Gombak), dalam temubual dengan pengkaji, 27 Oktober 2018.

44 Illani Binti Zulkifli (Mantan Jawatankuasa Tarbiah Belia Harmoni Universiti Islam Antarabangsa, Gombak), dalam temubual dengan pengkaji, 22 Oktober 2018. 
mahasiswa, aspek rohani merupakan salah satu aspek penting yang perlu diberi penekanan. Jadi, program katibah yang dilaksanakan merupakan program pembangunan mahasiswa yang menekankan aspek rohani. Namun, objektif mengenai ketaatan para ahli ke dalam semua program yang ditetapkan oleh jemaah merupakan objektif khusus yang tidak praktikal kepada semua peserta katibah.

Walau bagaimanapun, program katibah ini mempunyai bentuk pelaksanaannya yang tersendiri. Berdasarkan tujuan pelaksanaan katibah, dapat disenaraikan cara-cara pelaksanaannya. Menurut 'Alī 'Abd al-Ḥalīm Maḥmūd, beliau menyatakan bahawa sekiranya para peserta dianjurkan untuk berpuasa pada hari katibah, jadi katibah akan dimulakan dengan solat maghrib terlebih dahulu dan berbuka puasa dengan makanan yang berat. Jika pada hari katibah tersebut tidak dianjurkan untuk berpuasa secara beramai-ramai, maka program katibah akan dimulakan dengan mendirikan solat Isyak secara berjemaah. Selepas solat, mana-mana peserta katibah yang telah dilantik untuk menjadi ketua katibah pada waktu itu akan memberi kata-kata aluan dan memberi peringatan kepada peserta tentang adab dan tujuan katibah. Selesai sahaja ucapan dari ketua katibah, semua peserta akan disuruh untuk membaca ma'thurat secara bersendirian kecuali jika ada keperluan untuk membacanya secara berjemaah. Kemudian, para peserta akan melakukan solat malam, solat tahajud, beristighfar, berzikir dan berdoa kepada Allah. Selesai melakukan solat subuh, para peserta akan diajarkan tafsir beberapa ayat al-Quran yang dibacakan semasa wirid mengikut tema katibah. ${ }^{45}$

Bagi pelaksanaan katibah di UKM, Nur Zakiah Najihah mengatakan bahawa katibah berlaku dengan gabungan beberapa kelompok usrah dalam sesuatu kawasan. Peserta katibah akan tidur bersama-sama dan bangun malam untuk melakukan qiamullail secara berjemaah. Dalam program katibah, ahli-ahli Belia Harmoni juga mendapat pengisian berbentuk rohani seperti tazkirah, tilawah dan tadabbur serta perbincangan dan muhasabah diri.

45 'Alī 'Abd al-Ḥalīm Maḥmūd, Rukn al- 'Amal Aw Manhaj al-Islāh al-Islāmī li al-Farḍ wa al-Mujtama' (T.tp.: Dār al-Tawzī' wa al-Nashr al-Islāmiyyah, 1994), 22. 
Kebiasaannya, program katibah ini dilakukan di masjid atau surau. $^{46}$

Pada hari katibah, Siti Hajar menyatakan bahawa para peserta digalakkan untuk berpuasa sunat. Program akan bermula selepas solat maghrib. Selepas solat maghrib berjemaah, peserta-peserta katibah membaca ma'thurat bersama-sama. Sementara menanti waktu solat Isyak, para peserta mengadakan tilawah dan hafazan secara berkumpulan. ${ }^{47}$ Hal ini juga selari dengan pelaksanaan program katibah di UiTM Shah Alam yang dinyatakan oleh Abidah Masturah. Beliau menambah lagi,

Program katibah juga turut diisi dengan aktiviti membaca ma'thurat bersama-sama, solat berjemaah dan membaca alQuran bersama-sama. ${ }^{48}$

Di UPM, A'aisyah Mardiyyah menyatakan bahawa program katibah diadakan sebulan sekali atau dua bulan sekali di rumah yang ditetapkan. Para peserta diminta bermalam di rumah tersebut dan program katibah diketuai oleh wakil naqibah dari salah satu usrah yang terlibat. Program katibah diisi dengan melakukan ibadahibadah sunat seperti solat sunat berjemaah, bacaan ma'thurat berjemaah dan berzikir. Di samping itu juga, para peserta menerima pengisian mengenai sirah Rasulullah, para Sahabat dan Tabi 'in. ${ }^{49}$

Siti Saripa menjelaskan bahawa di UPM, program katibah bermula pada jam 6.30 petang dan para peserta katibah diminta untuk makan di dalam dulang bagi merapatkan lagi ukhuwah sesama peserta katibah. Walaupun tujuan utama program katibah adalah pembinaan rohani, elemen ukhuwah turut sama diterapkan. ${ }^{50}$ Illani juga mengatakan;

46 Nur Zakiah Najihah Bahar (Ahli Jawatankuasa (AJK) Belia Harmoni Universiti Kebangsaan Malaysia, Bangi), dalam temubual dengan pengkaji, 26 Oktober 2018.

47 Siti Hajar Mohammad (Jawatankuasa Pembangunan Mahasiswa (JKPM) IKRAM Bangi), dalam temubual dengan pengkaji, 5 Oktober 2018.

48 Abidah Masturah Mohd Jahiddin (Ahli Jawatankuasa (AJK) Belia Harmoni Universiti Teknologi Mara (UiTM), Shah Alam), dalam temubual dengan pengkaji, 31 Oktober 2018.

49 A'aisyah Mardhiyyah Mohammad Shahini (Ahli Jawatankuasa (AJK) Belia Harmoni Universiti Putra Malaysia), dalam temubual dengan pengkaji, 23 Oktober 2018.

50 Siti Saripa Rabiah Mat Lazim (Ahli Jawatankuasa (AJK) Belia Harmoni Universiti Putra Malaysia), dalam temubual dengan pengkaji, 22 Oktober 2018. 
Biasanya program katibah dilakukan dalam kelompok yang besar iaitu gabungan beberapa kumpulan usrah. Kami juga mengadakan program katibah di masjid UIA. ${ }^{51}$

Berdasarkan hasil temu bual pengkaji dengan informaninforman yang terlibat secara langsung mengatur program katibah, dapat disimpulkan bahawa pelaksanaan program katibah anjuran Belia Harmoni di Selangor hampir sama dengan pelaksanaan program katibah yang dilaksanakan oleh al-Ikhwān al-Muslimūn. Program katibah yang dianjurkan oleh Belia Harmoni dilaksanakan secara bermalam di tempat-tempat yang sesuai untuk melaksanakan ibadah umum dan khusus. Di samping itu, pengisian-pengisian rohani turut disampaikan kepada para ahli yang hadir bagi mencapai objektif program katibah tersebut.

\section{Rehlah}

Perkataan rehlah berasal dari perkataan Arab yang bermaksud berjalan dari satu tempat ke tempat yang lain. ${ }^{52}$ Dalam Bahasa Melayu, rehlah bermaksud berkelah. Menurut Kamus Dewan Bahasa dan Pustaka, berkelah bermaksud bersuka-suka dan berjamu beramai-ramai di luar rumah ${ }^{53}$ seperti di pantai, taman rekreasi dan tempat-tempat yang sesuai.

Program rehlah ini telah diperkenalkan oleh Hasan al-Banna sebagai salah satu program tarbiah al-Ikhwān al-Muslimūn. Program rehlah ini sama pentingnya dengan program usrah dan katibah, Cuma ia dilaksanakan dalam bentuk yang lebih santai. Menurut Hasan al-Banna, program rehlah ini boleh dilaksanakan dengan pelbagai cara selagi dapat mencapai objektif program tersebut. Antara aktiviti yang dicadangkan ialah mengadakan program rehlah berbentuk ilmiah seperti mengadakan lawatan ke muzium ataupun di mana-mana tempat bersejarah seperti tempattempat berlakunya peristiwa peperangan. Hasan al-Banna turut menyatakan bahawa program rehlah juga boleh dilaksanakan dengan tujuan riadah dengan memilih lokasi yang bersesuaian

51 Illani Zulkifli (Mantan Jawatankuasa Tarbiah Belia Harmoni Universiti Islam Antarabangsa, Gombak), dalam temubual dengan pengkaji, 22 Oktober 2018.

52 Al-Mu 'jam al-'Arabī al-Asāsī (ed. ke-1, Alesco: Larousse, 1989), 512, entri "rihlah".

53 Kamus Dewan Edisi Ketiga (cet. ke-4, Kuala Lumpur:, Dewan Bahasa dan Pustaka, 2002), 606, entri "kelah". 
seperti rehlah di tepi pantai, mendaki gunung atau melawat kawasan-kawasan pertanian. Aktiviti rehlah juga boleh dilakukan dengan melakukan aktiviti berbasikal secara berjemaah. ${ }^{54}$

Berdasarkan objektif dan pelaksanaan rehlah yang digariskan oleh al-Ikhwān al-Muslimūn, pengkaji mendapati bahawa Belia Harmoni juga melaksanakan perkara yang hampir sama dengannya. Kajian ini mendapati objektif program rehlah yang dilaksanakan oleh Belia Harmoni adalah untuk memberikan kesegaran kepada ahli Belia Harmoni dalam proses pembangunan mahasiswa. Kebanyakan program tarbiah dilaksanakan dalam suasana yang tertutup dan mengadakan perbincangan yang lebih serius. Jadi program rehlah yang dilakukan di tempat-tempat yang terbuka menjadikan para ahli lebih bersahaja dan santai menyertainya. Di samping itu juga, objektif yang dapat dicapai ketika program rehlah diadakan ialah dapat mengeratkan ukhuwah sesama ahli Belia Harmoni. Para peserta program dapat mempraktikkan kefahaman ithār iaitu mengutamakan keperluan orang lain secara praktikal.

Perkara ini turut dinyatakan oleh Siti Hajar bahawa Belia Harmoni melaksanakan rehlah yang dilakukan adalah untuk mengukuhkan ukhuwah dalam kalangan ahli Belia Harmoni. Di samping itu, rehlah juga dapat membantu setiap ahli untuk saling mengenali di antara satu sama lain dengan lebih mendalam. Selain itu, program rehlah juga dapat membuatkan para peserta menikmati keindahan alam dan merasai kekuasaan Pencipta. ${ }^{55}$

Nur Zakiah Najihah juga turut mengatakan bahawa tujuan utama program rehlah adalah untuk mengeratkan silaturahim dalam kalangan ahli dengan lebih santai. Beliau menyatakan lagi;

Bila sebut mengenai rehlah, saya teringat kisah Imam Hasan Al-Banna dan anggota-anggota al-Ikhwān al-Muslimūn. Saya teringat kisah mereka ketika ingin mengadakan program rehlah di Mesir yang mana apabila bas rehlah itu tiba ke tempat mereka berkumpul, para anggota Ikhwan berebut-rebut untuk naik bas dan memilih tempat duduk masing-masing. Ketika itu ada anggota Ikhwan yang berusia sedikit daripada anggotaanggota lain tidak dapat tempat duduk. Apabila Imam Hasan Al-Banna mengetahui perkara tersebut, beliau menyuruh

54 Hasan Al-Bannāa, Majmū'ah Rasā'il, 288.

55 Siti Hajar Mohammad (Jawatankuasa Pembangunan Mahasiswa (JKPM) IKRAM Bangi), dalam temubual dengan pengkaji, 5 Oktober 2018. 
semua anggota Ikhwan yang berada di dalam bas tersebut turun dan membatalkan program rehlah tersebut. Dalam kisah tersebut, Imam Hasan al-Banna ingin mengajar kepada anggota Ikhwan bahawa jika kita tidak boleh mementingkan ukhuwah kita daripada diri kita sendiri, maka objektif rehlah yang ingin dilaksanakan itu adalah sia-sia. ${ }^{56}$

A'aisyah Mardiyyah pula mengatakan bahawa tujuan program rehlah diadakan adalah untuk meningkatkan kekuatan fizikal melalui aktiviti riadah. ${ }^{57}$ Kenyataan ini bertepatan dengan isi kandungan dalam buku Majmü'ah al-Rasā'il mengenai program rehlah. Dalam buku tersebut, Hasan al-Banna ada menyatakan bahawa tujuan al-Ikhwān al-Muslimūn mengadakan program rehlah ini adalah untuk beriadah seperti rehlah di tepi pantai dan sungai, rehlah mendaki gunung dan bukit, rehlah berbasikal dan beraktiviti luar (outdoor) dan sebagainya. ${ }^{58}$

Abidah Masturah berpendapat bahawa tujuan program rehlah dilaksanakan adalah untuk merehatkan minda dan menyegarkan jiwa para ahli dengan aktiviti yang santai. Di samping itu juga, setiap ahli juga berpeluang untuk berekreasi bersama-sama. Beliau menyatakan lagi;

Bagi saya, program rehlah merupakan program yang sangat diminati oleh semua ahli kerana program ini adalah program yang santai. Kita yang jadi pelajar di universiti perlukan sesuatu program yang boleh menenangkan fikiran dan jiwa. Jadi program rehlah ini dapat membantu kita merehatkan fikiran serta dapat memberikan bekalan dan kekuatan rohani kerana dalam program juga terdapat pengisian yang mengajak kita sentiasa mendekatkan diri kepada Allah. ${ }^{59}$

Siti Umairah juga menjelaskan bahawa program rehlah ini merupakan salah satu bukti yang menunjukkan bahawa Belia

56 Nur Zakiah Najihah Bahar (Ahli Jawatankuasa (AJK) Belia Harmoni Universiti Kebangsaan Malaysia, Bangi), dalam temubual dengan pengkaji, 26 Oktober 2018.

57 A'aisyah Mardhiyyah Mohammad Shahini (Ahli Jawatankuasa (AJK) Belia Harmoni Universiti Putra Malaysia), dalam temubual dengan pengkaji, 23 Oktober 2018.

58 Hasan al-Banna, Majmū' āh al-Rasā'il, 288.

59 Abidah Masturah Mohd Jahiddin (Ahli Jawatankuasa (AJK) Belia Harmoni Universiti Teknologi Mara (UiTM), Shah Alam), dalam temubual dengan pengkaji, 31 Oktober 2018. 
Harmoni sangat mementingkan ukhuwah. Ia bertepatan dengan moto Pertubuhan IKRAM Malaysia iaitu "Ukhuwah Asas Kegemilangan". Menurut beliau lagi, program rehlah merupakan salah satu medium yang sangat penting untuk dilaksanakan kerana ia mampu membantu para ahli Belia Harmoni melalui program tarbiah dengan rasa tenang, bersahaja dan santai. ${ }^{60}$

Kajian mendapati bahawa objektif program rehlah yang dilaksanakan oleh Belia Harmoni kepada ahli-ahlinya bertepatan dengan objektif yang digariskan oleh al-Ikhwān al-Muslimūn. Ini menunjukkan bahawa Belia Harmoni telah berusaha untuk melahirkan ahli-ahli yang komited dalam mencapai objektif kesemua program tarbiah jemaah.

Pelaksanaan program rehlah bagi al-Ikhwān al-Muslimūn pula adalah untuk mencapai objektif dan mewujudkan suasana masyarakat yang Islami yang melibatkan tubuh badan seseorang sepanjang hari. ${ }^{61}$ Walau bagaimanapun, program rehlah boleh dilaksanakan secara santai selagi ia boleh mencapai objektif rehlah itu sendiri.

Bagi pelaksanaan program rehlah di UKM, Nur Zakiah Najihah mengatakan bahawa aktiviti yang dilakukan semasa program rehlah berlangsung adalah lebih santai dan berbentuk outdoor. Walau bagaimanapun, pengisian ringkas berbentuk tazkirah turut disampaikan oleh penganjur program. ${ }^{62}$ Siti Hajar menambah lagi;

Kebiasaannya program rehlah dilaksanakan di tempat-tempat rekreasi ataupun di taman-taman yang bersesuaian. Program rehlah juga dimulai dengan membaca beberapa potong ayat alQuran oleh pengerusi majlis, disusuli dengan pengisian ringkas yang mengajak para peserta untuk sentiasa mengingati dan mensyukuri nikmat Allah dan kemudian kami akan melakukan aktiviti-aktiviti fizikal yang dapat membantu untuk merapatkan ukhuwah. ${ }^{63}$

60 Siti Umairah Idris (Jawatankuasa Pembangunan Mahasiswa (JKPM) IKRAM Shah Alam), dalam temubual dengan pengkaji, 21 Oktober 2018.

61 Ibid.

62 Nur Zakiah Najihah Bahar (Ahli Jawatankuasa (AJK) Belia Harmoni Universiti Kebangsaan Malaysia, Bangi), dalam temubual dengan pengkaji, 26 Oktober 2018.

63 Siti Hajar Mohammad (Jawatankuasa Pembangunan Mahasiswa (JKPM) IKRAM Bangi), dalam temubual dengan pengkaji, 5 Oktober 2018. 
Menurut A'aisyah Mardhiyyah, di UPM kebiasaannya program rehlah ini mempunyai aktiviti fizikal seperti beriadah untuk mengeluarkan peluh. Beliau juga menjelaskan bahawa program rehlah ini juga dapat membantu memenuhi 10 ciri keperibadian muslim yang digariskan oleh al-Ikhwān al-Muslimūn iaitu sihat tubuh badan. Di samping itu, turut diadakan acara jamuan ringkas yang dibuat secara potluck. ${ }^{64}$

Menurut Abidah Masturah, aktiviti yang sering dilakukan semasa program rehlah diadakan oleh ahli Belia Harmoni di UiTM Shah Alam ialah aktiviti picnic, hiking, berjalan-jalan di taman atau tasik dan sebagainya. ${ }^{65}$ Siti Umairah juga mengatakan bahawa program rehlah diadakan di tempat-tempat yang sesuai untuk berkumpul dan terbuka seperti di taman rekreasi, tasik dan sebagainya. Beliau menyatakan lagi;

Dalam program rehlah biasanya aktiviti-aktiviti outdoor seperti hiking, flying fox, futsal, badminton, bola jaring dan sebagainya akan dianjurkan. Walaupun program rehlah ini nampak macam program fizikal sahaja, tetapi tidak dilupakan juga sesi tazkirah yang sentiasa mengingatkan para peserta supaya sentiasa dalam keadaan mengingati Allah. ${ }^{66}$

Aliyah menyatakan program rehlah di UIA Gombak dilaksanakan satu kali pada setiap semester. Hal ini kerana, program rehlah merupakan program besar yang juga melibatkan ramai ahli. Jadual pelajar yang padat menjadi kekangan untuk para ahli berkumpul dalam satu program. Jadi, pelaksanaan sekali bagi setiap satu semester sangat memadai untuk mengumpulkan kesemua ahli yang terlibat. Pengisian dalam program rehlah juga lebih bertemakan ukhuwah sesuai dengan objektif utama program. ${ }^{67}$

64 A'aisyah Mardhiyyah Mohammad Shahini (Ahli Jawatankuasa (AJK) Belia Harmoni Universiti Putra Malaysia), dalam temubual dengan pengkaji, 23 Oktober 2018.

65 Abidah Masturah Mohd Jahiddin (Ahli Jawatankuasa (AJK) Belia Harmoni Universiti Teknologi Mara (UiTM), Shah Alam), dalam temubual dengan pengkaji, 31 Oktober 2018.

66 Siti Umairah Idris (Jawatankuasa Pembangunan Mahasiswa (JKPM) IKRAM Shah Alam), dalam temubual dengan pengkaji, 21 Oktober 2018.

67 Aliyah Ahmad Bahari (Jawatankuasa PembangunanMahasiswa (JKPM) Universiti Islam Antarabangsa, Gombak), dalam temubual dengan pengkaji, 27 Oktober 2018. 
Menurut Illani pula, program rehlah biasanya diadakan secara gabungan usrah dalam kumpulan yang lebih besar. ${ }^{68}$

Melalui hasil temu bual pengkaji dengan para informan mengenai pelaksanaan program rehlah, dapat disimpulkan bahawa program rehlah yang dilaksanakan oleh Belia Harmoni di Selangor hampir sama di setiap universiti awam Selangor. Walau bagaimanapun, terdapat sedikit perbezaan dari segi waktu dan tempat pelaksanaan program tersebut kerana setiap universiti mempunyai jadual dan lokasi yang berbeza.

\section{Mukhayyam}

Perkataan mukhayyam berasal dari perkataan Arab yang bermaksud tempat untuk mengadakan aktiviti seperti riadah ataupun aktiviti yang melatih kemahiran-kemahiran asas kehidupan. ${ }^{69}$ Manakala mukhayyam dalam Bahasa Melayu pula diterjemahkan sebagai perkhemahan. Menurut Kamus Dewan, perkataan perkhemahan bermaksud kelompok (kumpulan) berkhemah dengan mendirikan dan memasang khemah untuk berteduh atau bermalam. ${ }^{70}$

Menurut Mahmud 'Abd Halim, program mukhayyam dilaksanakan bagi tujuan untuk melatih sifat sabar dalam menghadapi apa sahaja situasi sama ada susah ataupun senang. Beliau mengatakan bahawa program mukhayyam merupakan program susulan selepas program rehlah kerana kedua-dua program ini melibatkan daya ketahanan tubuh badan ahli Ikhwan. Beliau juga menjelaskan bahawa dalam program mukhayyam terdapat tiga elemen yang diterapkan kepada para ahli iaitu elemen tajmi " (perkumpulan), tarbiyah (didikan) dan tadrīb (latihan) sebagai langkah persediaan untuk berdakwah kepada masyarakat. ${ }^{71}$

Menurut Siti Hajar, objektif pelaksanaan mukhayyam di UKM adalah untuk menguatkan jasmani dan daya tahan sebagai seorang pejuang dakwah. Selain itu juga, tujuan program mukhayyam ini

68 Illani Binti Zulkifli (Mantan Jawatankuasa Tarbiah Belia Harmoni Universiti Islam Antarabangsa, Gombak), dalam temubual dengan pengkaji, 22 Oktober 2018.

69 Al-Mu 'jam al-'Arabī al-Asās̄̄ (ed. 1, Alesco: Larousse, 1989), 433, entri "mukhayyam".

70 Kamus Dewan Edisi Ketiga (cet. ke-3, Kuala Lumpur: Dewan Bahasa dan Pustaka, 1994), 673, entri "khemah".

71 Maḥmūd 'Abd al-Ḥalīm, Al-Ikhwān al-Muslimūn - Ahdāth Șana'at al-Tārīkh Ru'yatun Min al-Dākhīl (Kaherah: Dār al-Da'wah, 2004), 1:185. 
adalah untuk menambah pengetahuan bagi tajuk-tajuk tertentu yang seharusnya dikuasai oleh setiap ahli Belia Harmoni. Hal ini kerana, setiap ahli memerlukan kefahaman Islam yang benar dalam melaksanakan dakwah dan tarbiah. ${ }^{72}$

Manakala A'isyah Mardhiyyah pula menyatakan bahawa program mukhayyam ini bertujuan untuk melatih para ahli Belia Harmoni mempunyai semangat jihad yang tinggi. Program mukhayyam merupakan satu-satunya program tarbiah yang menggunakan latihan fizikal yang lasak dan mencabar. Beliau menyatakan lagi,

Bagi saya, semangat perjuangan dakwah sangat memerlukan seorang pendakwah yang mempunyai jiwa yang kental dan kekuatan fizikal yang mantap supaya para pendakwah dapat mengharungi segala cabaran dan tribulasi yang menanti ketika melaksanakan kerja-kerja dakwah. ${ }^{73}$

Di UiTM Shah Alam, Abidah Masturah mengatakan bahawa objektif program mukhayyam ini adalah untuk para peserta melalui tarbiah berbentuk latihan fizikal, simulasi disiplin, persiapan untuk menghadapi masyarakat dan latihan ketaatan agar para peserta bersedia untuk menjadi pejuang dakwah di medan dakwah yang sebenar. Di samping itu juga, program mukhayyam ini ialah satu program yang akan mendorong seseorang untuk melakukan perubahan diri secara sukarela ke arah membina kekuatan dalaman bagi merubah sikap dan tingkah laku, seterusnya dapat memupuk tabiat-tabiat yang cemerlang. ${ }^{74}$

Aliyah mengatakan bahawa program mukhayyam di UIA Gombak adalah bertujuan untuk membina kekuatan jasmani, fikrah dan dakwah. Selain melakukan aktiviti-aktiviti berbentuk latihan fizikal, para peserta juga perlu mendengar pengisian yang membina

72 Siti Hajar Mohammad (Jawatankuasa Pembangunan Mahasiswa (JKPM) IKRAM Bangi), dalam temubual dengan pengkaji, 5 Oktober 2018.

73 A'aisyah Mardhiyyah Binti Mohammad Shahini (Ahli Jawatankuasa (AJK) Belia Harmoni Universiti Putra Malaysia), dalam temubual dengan pengkaji, 23 Oktober 2018.

74 Abidah Masturah Mohd Jahiddin (Ahli Jawatankuasa (AJK) Belia Harmoni Universiti Teknologi Mara (UiTM), Shah Alam), dalam temubual dengan pengkaji, 31 Oktober 2018. 
fikrah Islam dalam melaksanakan dakwah supaya setiap peserta yang hadir dapat melalui proses tarbiah secara holistik. ${ }^{75}$

Nusaibah menjelaskan bahawa program mukhayyam ini bertujuan untuk mengumpulkan ahli di samping mentarbiah para ahli dengan tarbiah mengikut objektif dan tarbiah berdasarkan pengalaman yang dilalui. Beliau juga menyatakan;

Program mukhayyam ini biasanya dijadikan sebagai medium untuk pelatihan nilai-nilai bekerja dalam organisasi seperti 'amal jama' $i$ dan penerapan nilai untuk sentiasa berbincang sesama ahli kumpulan sebelum membuat keputusan (syura). Nilai-nilai ini perlu ada dalam diri setiap pejuang dakwah kerana kerja-kerja dakwah dilakukan secara berkelompok dan mempunyai strategi tersendiri untuk mencapai matlamat dakwah yang lebih besar. ${ }^{76}$

Objektif program mukhayyam yang diadakan oleh Belia Harmoni di Selangor mempunyai persamaan dengan objektif program mukhayyam yang dilaksanakan oleh al-Ikhwān alMuslimūn iaitu untuk membentuk kehidupan ahli dengan acuan Islam dalam satu tempoh masa tertentu dalam beberapa hari, mencorak akhlak Islami dan adab-adab mengikut al-Quran dan asSunnah. Di samping itu juga, program mukhayyam ini dapat melatih ahli untuk merasai suasana seperti di sebuah kem ketenteraan dalam segenap aspek seperti taat, tersusun, tolak ansur, disiplin, patuh serta praktikal memikul amanah dan mengambil serius tanggungjawab dan nilai sebuah amanah. ${ }^{77}$

Bagi pelaksanaan program mukhayyam pula Siti Hajar mengatakan bahawa program mukhayyam ini dilaksanakan sekali setahun. Idea pelaksanaan program mukhayyam ini diadaptasi dari kisah-kisah perang yang dilalui oleh Rasulullah SAW dan para sahabat baginda. Di samping itu juga, para peserta akan menerima pengisian yang berbentuk haraki (bergerak) supaya para peserta dapat meningkatkan kefahaman dakwah dan merasakan bahawa

75 Aliyah Ahmad Bahari (Jawatankuasa PembangunanMahasiswa (JKPM) Universiti Islam Antarabangsa, Gombak), dalam temubual dengan pengkaji, 27 Oktober 2018.

76 Nusaibah Mohammad (Ahli Jawatankuasa Belia Harmoni Universiti Islam Antarabangsa, Gombak), dalam temubual dengan pengkaji, 27 Oktober 2018.

77 Ahmad Rabī’ a'Abd al-Hamīd Khalif, Al-Fikr al-Tarbawī wa Taṭbīqāt ladā Jama'at al-Ikhwān al-Muslimīn, 186. 
ummah ini memerlukan lebih ramai pendakwah yang bekerja untuk meningkatkan Islam. ${ }^{78}$

Menurut Nur Zakiah Najihah pula, program mukhayyam ini dilaksanakan pada awal tahun. Program mukhayyam ini akan melibatkan beberapa kumpulan usrah yang lain. Menurut beliau lagi;

Aktiviti-aktiviti yang dilakukan sepanjang program mesti mempunyai latihan berbentuk fizikal dan mental, menguji fikrah dan memantapkan ukhuwah. Jadi, pengarah program perlu memikirkan apa aktiviti yang sesuai untuk dimasukkan ke dalam program. ${ }^{79}$

A'aisyah Mardhiyyah mengatakan bahawa program mukhayyam kebiasaannya dilakukan selama tiga hari dua malam di kem-kem yang bersesuaian dengan program. Pada waktu selepas subuh dan selepas Isya', para peserta akan mendengar pengisian dari penceramah jemputan mengenai kefahaman dakwah. Aktivitiaktiviti pada waktu siang pula diadakan aktiviti outdoor seperti explorace, jungle tracking, flying fox dan sebagainya. A'aisyah juga menyatakan;

Semua aktiviti dalam program mukhayyam mesti dilakukan secara berkumpulan kerana para peserta akan dilatih untuk menyelesaikan semua tugasan yang diberikan secara berkumpulan, bukan secara individu. ${ }^{80}$

Menurut Siti Umairah, program mukhayyam ini dilaksanakan mengikut silibus yang telah ditetapkan oleh JK Tarbiah Belia Harmoni. Walau bagaimanapun, cara pelaksanaan program mukhayyam ini ialah bebas selagi mana tidak lari dari objektif yang telah ditetapkan oleh JK Tarbiah. Aktiviti yang dinyatakan oleh Siti Umairah juga hampir sama dengan cara pelaksanaan di universitiuniversiti yang lain. ${ }^{81}$

78 Siti Hajar Mohammad (Jawatankuasa Pembangunan Mahasiswa (JKPM) IKRAM Bangi), dalam temubual dengan pengkaji, 5 Oktober 2018.

79 Nur Zakiah Najihah Bahar (Ahli Jawatankuasa (AJK) Belia Harmoni Universiti Kebangsaan Malaysia, Bangi), dalam temubual dengan pengkaji, 26 Oktober 2018.

80 A'aisyah Mardhiyyah BintiMohammad Shahini (Ahli Jawatankuasa (AJK) Belia Harmoni Universiti Putra Malaysia), dalam temubual dengan pengkaji, 23 Oktober 2018.

81 Siti Umairah Idris (Jawatankuasa Pembangunan Mahasiswa (JKPM) IKRAM Shah Alam), dalam temubual dengan pengkaji, 21 Oktober 2018. 
Aliyah mengatakan bahawa pelaksanaan program mukhayyam di UIA Gombak dimulakan selepas solat Isya' dengan taklimat berkenaan peraturan mukhayyam yang perlu dipatuhi oleh para peserta, mind setting dan perbincangan tugasan dalam kumpulan yang telah ditetapkan. Aktiviti pagi dimulakan dengan aktiviti menziarahi shuyūkh IKRAM sebelum bertolak ke tempat perkhemahan. Aliyah menyatakan lagi,

Apabila para peserta telah sampai di kem, mereka akan menyertai slot pengisian, aktiviti fizikal dan slot tazkirah yang akan disampaikan oleh wakil setiap kumpulan. Aktiviti-aktiviti lain juga akan disusun mengikut keperluan peserta seperti aktiviti kebudayaan dan lain-lain. ${ }^{82}$

Menurut Nusaibah, program mukhayyam ini dilaksanakan melalui gabungan usrah mengikut peringkat tarbiah yang sama dan diadakan di kawasan perkhemahan atau calet. Aturcara dan pengisian program ini lebih menghala ke arah mendisiplinkan diri dan nilai ketenteraan atau pengkaderan. Selain itu juga, turut diselitkan aktiviti-aktiviti jasmani seperti riadah ringkas bagi memenuhi muwasafat tarbiyah iaitu qawi al-jism (sihat tubuh badan).$^{83}$

Hasil temu bual dengan para informan, kajian ini mendapati bahawa pelaksanaan program mukhayyam yang dilaksanakan oleh Belia Harmoni di Selangor memenuhi keperluan objektif yang telah ditetapkan seperti membina ketahanan fizikal, semangat jihad dan didikan rohani. Pelaksanaan program mukhayyam setiap universiti di Selangor juga hampir sama seperti dilaksanakan secara gabungan beberapa kumpulan usrah dan dilaksanakan selama tiga hari dua malam. Walau bagaimanapun, lokasi program mukhayyam diadakan di lokasi berbeza mengikut kawasan masing-masing.

82 Aliyah Ahmad Bahari (Jawatankuasa PembangunanMahasiswa (JKPM) Universiti Islam Antarabangsa, Gombak), dalam temubual dengan pengkaji, 27 Oktober 2018.

83 Nusaibah Mohammad (Ahli Jawatankuasa Belia Harmoni Universiti Islam Antarabangsa, Gombak), dalam temubual dengan pengkaji, 27 Oktober 2018. 


\section{Daurah}

Menurut Abd Rauf, daurah bermaksud pusingan, putaran atau kursus. ${ }^{84}$ Manakala menurut 'Alī Abd al-Halīm Mạ̣mūd, program ini dinamakan daurah kerana ia merupakan program yang dilaksanakan secara berkala pada waktu yang tertentu. Ia juga diberi maksud sebagai pengumpulan sejumlah ahli sesuatu kumpulan yang ramai di sesuatu tempat untuk mendengar ceramah, kajian, penelitian dan latihan tentang sesuatu perkara yang berkaitan dengan tema kerohanian yang membangkitkan semangat. ${ }^{85}$

Program daurah yang diadakan adalah bertujuan untuk membentuk kefahaman dan pemikiran para ahli mengenai fikrah dakwah dan tarbiah Islamiyyah seperti yang dituntut oleh Al-Quran dan al-Sunnah. Oleh itu, para ahli akan diberi pengisian berbentuk fikri, haraki dan ruhi. Pengisian yang berbentuk fikri biasanya menjelaskan kepada ahli mengenai konsep Islam yang sebenar serta mengupas isu-isu yang berkaitan dengan hal ehwal Islam secara terperinci. ${ }^{86}$

A'aisyah Mardhiyyah mengatakan bahawa pelaksanaan program daurah ini adalah untuk membantu para ahli Belia Harmoni menambahkan lagi kefahaman terhadap dakwah ini. ${ }^{87}$ Manakala Siti Saripa Rabiah menjelaskan bahawa program daurah ini bertujuan untuk melatih dan membimbing ahli mengenai kemahiran-kemahiran asas dalam dakwah dan tarbiah. ${ }^{88} \mathrm{Di}$ samping itu juga, Nur Zakiah Najihah menjelaskan lagi bahawa program daurah ini dapat dijadikan sebagai medium perkongsian pengalaman secara praktikal daripada penyampai yang berpengalaman. ${ }^{89}$

84 Abd. Rauf Dato' Hj. Hassan, et.al. Kamus al-Lughah al-Malayuwiyyah - AlLughah al- 'Arabiyyah (Shah Alam: Dewan Pustaka Fajar, 2005), 145, entri "dara Yaduru".

85 'Alī 'Abd al-Ḥalīm Maḥmūd, Wasā'il al-Tarbiyah 'inda al-Ikhwān alMuslimin: Dirāsah Taḥlīliyyah Tārīkhiyah, 286.

86 Sa'̄̄d Hawwa, F̄̄ Áfāq al-Ta'lim (Kaherah: Maktabah Wahbah, 1980), 197-199.

87 A'aisyah Mardhiyyah Mohammad Shahini (Ahli Jawatankuasa (AJK) Belia Harmoni Universiti Putra Malaysia), dalam temubual dengan pengkaji, 23 Oktober 2018.

88 Siti Saripa Rabiah Mat Lazim (Ahli Jawatankuasa (AJK) Belia Harmoni Universiti Putra Malaysia), dalam temubual dengan pengkaji, 22 Oktober 2018.

89 Nur Zakiah Najihah Bahar (Ahli Jawatankuasa (AJK) Belia Harmoni Universiti Kebangsaan Malaysia, Bangi), dalam temubual dengan pengkaji, 26 Oktober 2018. 
Menurut Abidah Masturah, objektif utama program daurah adalah untuk memberi pengisian mengikut silibus yang tidak dapat dilaksanakan di dalam usrah. Beliau menjelaskan;

Silibus kita agak banyak. Jadi, pihak JK Tarbiah Belia Harmoni sudah membahagikan semua silibus kepada kategori wasilah tarbiah mengikut kesesuaian. Kebiasaannya, bahanbahan daurah adalah bahan-bahan yang perlu disampaikan kepada beberapa kumpulan usrah secara serentak untuk penyelarasan kefahaman. ${ }^{90}$

Siti Umairah juga menjelaskan bahawa program daurah ini bertujuan untuk membentuk fikrah para ahli mengikut fikrah dakwah yang sebenar. Beliau menjelaskan lagi;

Ada sebahagian bahan fikrah perlu disampaikan melalui wasilah daurah untuk memastikan para ahli Belia Harmoni faham konsep dakwah Ikhwan yang sebenar. Biasanya kami akan mencari muwajjih yang pakar untuk menyampaikan bahan-bahan fikrah yang agak berat. ${ }^{91}$

Hasil temu bual dengan Aliyah, beliau juga menyatakan perkara yang sama dengan Siti Umairah. Beliau menyatakan bahawa program daurah selalunya memfokuskan kepada pemantapan bahan berbentuk fikrah dakwah. Beliau menyatakan lagi bahawa bukan semua naqibah mampu menjelaskan dengan baik sebahagian bahan-bahan fikrah yang ditetapkan oleh JK Tarbiah. ${ }^{92}$ Hal ini turut dinyatakan oleh Illani dengan menyatakan;

Program daurah ini sebenarnya dapat membantu para ahli menguasai bahan-bahan fikrah yang dapat membentuk kefahaman mereka dalam dakwah ini. ${ }^{93}$

Hasil dapatan kajian mengenai objektif program daurah yang dilaksanakan oleh Belia Harmoni adalah untuk membina kefahaman fikrah Islam dan fikrah dakwah ke dalam diri ahli Belia

90 Abidah Masturah Mohd Jahiddin (Ahli Jawatankuasa (AJK) Belia Harmoni Universiti Teknologi Mara (UiTM), Shah Alam), dalam temubual dengan pengkaji, 31 Oktober 2018.

91 Siti Umairah Idris (Jawatankuasa Pembangunan Mahasiswa (JKPM) IKRAM Shah Alam), dalam temubual dengan pengkaji, 21 Oktober 2018.

92 Aliyah Ahmad Bahari (Jawatankuasa PembangunanMahasiswa (JKPM) Universiti Islam Antarabangsa, Gombak), dalam temubual dengan pengkaji, 27 Oktober 2018.

93 Illani Zulkifli (Mantan Jawatankuasa Tarbiah Belia Harmoni Universiti Islam Antarabangsa, Gombak), dalam temubual dengan pengkaji, 22 Oktober 2018. 
Harmoni. Setiap ahli Belia Harmoni perlu jelas dan yakin dengan manhaj dan silibus yang dibawa oleh Belia Harmoni sebagai usaha untuk pembangunan mahasiswa. Di samping itu juga, objektif yang dapat dicapai dalam program daurah ini adalah untuk melatih dan menyediakan ahli Belia Harmoni pelbagai kemahiran asas dalam melaksanakan program tarbiah yang dapat membantu proses pembangunan mahasiswa.

Bagi pelaksanaan program daurah pula, A'aisyah Mardhiyyah menyatakan bahawa program daurah di UPM dilaksanakan sebulan sekali. Kebiasaannya program daurah ini melibatkan beberapa kumpulan usrah dan diuruskan oleh barisan para naqibah. ${ }^{94}$ Walau bagaimanapun, menurut Abidah Masturah;

Di UiTM, program daurah yang dilaksanakan sangat bergantung kepada keperluan semasa dan kemungkinan program daurah boleh dilaksanakan sebanyak dua bulan sekali. ${ }^{95}$

Menurut Siti Saripa Rabiah, beliau mengatakan bahawa program daurah yang dilaksanakan mempunyai dua bahagian. Bahagian pertama ialah sesi pengisian yang membentuk fikrah dan disampaikan oleh penceramah yang berpengalaman dalam medan dakwah dan tarbiah. Manakala bahagian yang kedua pula ialah bengkel kefahaman. Bengkel kefahaman ini biasanya dikendalikan oleh barisan naqibah-naqibah usrah supaya dapat membantu menjelaskan lagi kefahaman peserta. ${ }^{96}$

Siti Umairah menjelaskan lagi bahawa, tajuk daurah yang akan disampaikan kepada peserta adalah merujuk kepada silibus tarbiah yang telah digariskan oleh JK Tarbiah IKRAM Pusat mengikut peringkat-peringkat ahli. Beliau juga menyatakan;

Kesediaan mental dan fizikal para peserta sangat penting untuk menerima pengisian yang berbentuk fikrah dan harakah. Oleh itu, para naqibah perlu memastikan para mutarabbi masingmasing telah diingatkan untuk menerangkan pengenalan tajuk

94 A'aisyah Mardhiyyah Mohammad Shahini (Ahli Jawatankuasa (AJK) Belia Harmoni Universiti Putra Malaysia), dalam temubual dengan pengkaji, 23 Oktober 2018.

95 Abidah Masturah Mohd Jahiddin (Ahli Jawatankuasa (AJK) Belia Harmoni Universiti Teknologi Mara (UiTM), Shah Alam), dalam temubual dengan pengkaji, 31 Oktober 2018.

96 Siti Saripa Rabiah Mat Lazim (Ahli Jawatankuasa (AJK) Belia Harmoni Universiti Putra Malaysia), dalam temubual dengan pengkaji, 22 Oktober 2018. 
pengisian yang akan disampaikan di dalam kumpulan usrah masing-masing terlebih dahulu. ${ }^{97}$

Di UIA Gombak pula, Nusaibah menyatakan bahawa program daurah dilaksanakan pada sebelah malam hari bekerja kerana waktu tersebut para ahli kurang aktiviti-aktiviti kampus. Jadi program ini biasanya dilakukan selepas solat Isyak dan tamat pada hari yang sama. Menurut beliau lagi, program daurah ini mengumpulkan ahli Belia Harmoni untuk diberi fikrah atau penjelasan berkaitan hal-hal tertentu. ${ }^{98}$ Aliyah menjelaskan lagi bahawa program daurah ini dilaksanakan mengikut keperluan semasa para ahli. ${ }^{99}$

Berdasarkan maklumat yang diterima dari para informan mengenai pelaksanaan program daurah ini, kajian mendapati bahawa program daurah juga merupakan program yang melibatkan beberapa kumpulan usrah. Hal ini sangat penting untuk menyelaraskan kefahaman setiap ahli supaya semua yang mendengar pengisian tersebut menerima kefahaman yang sama. Kebiasaannya, program daurah yang dilaksanakan adalah sebagai medium menyampaikan bahan fikrah yang berbentuk haraki. Walau bagaimanapun, kajian mendapati bahawa tajuk pengisian dalam program daurah adalah berbeza mengikut universiti kerana tajuk yang dipilih perlu mengikut keperluan ahli di universiti masing-masing. Namun, tajuk-tajuk yang dipilih masih lagi berdasarkan silibus yang telah disediakan oleh JK Tarbiah IKRAM Pusat.

\section{Mu'tamar}

Perkataan mu'tamar berasal dari perkataan Arab bermaksud tempat bermesyuarat. Mu'tamar merupakan sebuah forum yang dihadiri oleh para ahli yang berpersonaliti baik, penyokong, para ilmuwan dan pimpinan sesuatu organisasi untuk mengkaji dan membincangkan sesuatu permasalahan. Hasil perbincangan tersebut akan disebarkan dan diberi kefahaman kepada semua yang hadir dalam forum tersebut. Manakala menurut Lembaga Bahasa

97 Siti Umairah Idris (Jawatankuasa Pembangunan Mahasiswa (JKPM) IKRAM Shah Alam), dalam temubual dengan pengkaji, 21 Oktober 2018.

98 Nusaibah Mohammad (Ahli Jawatankuasa Belia Harmoni Universiti Islam Antarabangsa, Gombak), dalam temubual dengan pengkaji, 27 Oktober 2018.

99 Aliyah Ahmad Bahari (Jawatankuasa PembangunanMahasiswa (JKPM) Universiti Islam Antarabangsa, Gombak), dalam temubual dengan pengkaji, 27 Oktober 2018. 
Arab di Mesir menyatakan bahawa maksud mu'tamar ialah forum untuk membincangkan atau membahaskan mengenai sesuatu persoalan. ${ }^{100}$

Dalam melaksanakan program mu'tamar, pengarah program perlu memastikan bahawa pemilihan penceramah atau pembahas merupakan seorang yang arif mengenai tajuk yang akan dibincangkan serta mempunyai pengalaman. Pengarah program juga perlu menentukan kesesuaian tajuk mu'tamar dengan tahap hadirin yang akan hadir ke mu 'tamar. Di samping itu juga, pengarah program perlu mencari tempat yang lebih besar bagi menampung bilangan hadirin yang ramai ke program mu'tamar. ${ }^{101}$

Menurut Siti Hajar, objektif program mu'tamar yang dilaksanakan di UKM adalah untuk mengumpulkan semua ahli di dalam UKM untuk memperkasakan peranan mahasiswa sebagai agen pemacu perubahan ummah. Siti Hajar menyatakan lagi,

Antara objektif lain yang dapat dicapai melalui program ти 'tamar adalah untuk menyemai semangat ukhuwah dalam kalangan ahli Belia Harmoni dan membina serta menyatukan kefahaman dakwah dan tarbiah dalam kalangan peserta. ${ }^{102}$

Nur Zakiah Najihah pula berpendapat bahawa objektif utama pelaksanaan program mu'tamar ini adalah untuk mendedahkan para peserta dengan isu semasa yang disolusikan bersama fikrah Islam yang benar. Akhirnya untuk diaplikasikan selepas mu 'tamar. ${ }^{103} \mathrm{Di}$ samping itu, Siti Umairah mengatakan bahawa para peserta juga akan dibentangkan mengenai perancangan program-program dakwah dan tarbiah serta pelaporan program-program yang telah dilaksanakan oleh Belia Harmoni bagi tujuan penambahbaikan. ${ }^{104}$

A'aisyah Mardhiyyah menjelaskan bahawa objektif program mu'tamar ini adalah untuk menyelaraskan kefahaman dakwah

100 'Alī 'Abd al-Ḥalīm Mạ̣mūd, Wasā'il al-Tarbiyah 'inda al-Ikhwān alMuslimin: Dirāsah Taḥlīilyyah Tārīkhiyah, 312.

101 'Alī 'Abd al-Halīm Maḥmūd, Wasā'il al-Tarbiyah 'inda al-Ikhwān alMuslimin: Dirāsah Taḥlīliyyah Tārīkhiyah, 312.

${ }^{102}$ Siti Hajar Mohammad (Jawatankuasa Pembangunan Mahasiswa (JKPM) IKRAM Bangi), dalam temubual dengan pengkaji, 5 Oktober 2018.

${ }^{103}$ Nur Zakiah Najihah Bahar (Ahli Jawatankuasa (AJK) Belia Harmoni Universiti Kebangsaan Malaysia, Bangi), dalam temubual dengan pengkaji, 26 Oktober 2018.

${ }^{104}$ Siti Umairah Idris (Jawatankuasa Pembangunan Mahasiswa (JKPM) IKRAM Shah Alam), dalam temubual dengan pengkaji, 21 Oktober 2018. 
dalam kalangan ahli. Beliau mengatakan bahawa sebahagian ahli mempunyai kefahaman tersendiri dalam satu tajuk pengisian yang sama. Jadi, beliau menerangkan,

Penyelarasan kefahaman dalam kalangan ahli sangat penting supaya gerak kerja dakwah dapat berjalan dengan lancar. Jika para ahli mempunyai kefahaman yang berbeza, perselisihan mudah berlaku dan menyukarkan jemaah untuk mencapai matlamat yang telah ditetapkan. ${ }^{105}$

Selain itu, Illani mengatakan bahawa program ini juga dilaksanakan bertujuan untuk memperkenalkan barisan kepimpinan Belia Harmoni dalam kalangan mahasiswa kepada ahli-ahlinya. ${ }^{106}$

Kajian ini mendapati bahawa objektif bagi program mu'tamar yang dilaksanakan oleh Belia Harmoni adalah untuk membincangkan gerak kerja dakwah dan tarbiah Belia Harmoni dalam universiti. Hasil perbincangan tersebut dijadikan sebagai resolusi dan cadangan penambahbaikan yang perlu dilaksanakan oleh semua cawangan Belia Harmoni dalam universiti di seluruh negara.

Pelaksanaan program ini pula dilaksanakan secara gabungan semua usrah yang melibatkan para ahli Belia Harmoni di seluruh negara. Program mu'tamar yang sering dianjurkan oleh Belia Harmoni dinamakan HARMONI menjadi platform kepada para pimpinan Belia Harmoni Pusat untuk membentangkan strategi dan gerak kerja dakwah Belia Harmoni kepada para ahli. Menurut Aliyah, program mu'tamar dilaksanakan sekali setahun. Kebiasaannya program ini akan dikendalikan oleh barisan kepimpinan mahasiswa Belia Harmoni kepada para ahlinya. Dalam mu'tamar ini, barisan kepimpinan akan menyampaikan mesejmesej penting dari JK Pembangunan Mahasiswa IKRAM Pusat dan Kawasan kepada para ahli. Di samping itu, para ahli turut berpeluang mendengar amanat dan nasihat dari wakil kepimpinan IKRAM Pusat. ${ }^{107}$

105 A'aisyah Mardhiyyah Mohammad Shahini (Ahli Jawatankuasa (AJK) Belia Harmoni Universiti Putra Malaysia), dalam temubual dengan pengkaji, 23 Oktober 2018.

106 Illani Zulkifli (Mantan Jawatankuasa Tarbiah Belia Harmoni Universiti Islam Antarabangsa, Gombak), dalam temubual dengan pengkaji, 22 Oktober 2018.

107 Aliyah Ahmad Bahari (Jawatankuasa PembangunanMahasiswa (JKPM) Universiti Islam Antarabangsa, Gombak), dalam temubual dengan pengkaji, 27 Oktober 2018. 
Nusaibah menyatakan bahawa pelaksanaan program mu 'tamar ini kebiasaannya akan membincangkan topik tertentu berkenaan dengan strategi pergerakan dakwah dalam universiti. Beliau menjelaskan;

Dalam program mu'tamar, para hadirin akan mendengar pengisian-pengisian ilmiah oleh penceramah jemputan yang berpengalaman dalam pelaksanaan dakwah di kampus. Jadi, secara tidak langsung kami dapat menjadikan pengalaman tersebut sebagai panduan dalam gerak kerja dakwah kami. ${ }^{108}$

Hasil kajian ini mendapati bahawa program mu'tamar dilakukan secara gabungan semua usrah yang melibatkan para ahli Belia Harmoni di seluruh negara. Program muktamar juga turut dijadikan sebagai medium perkongsian daripada wakil ahli IKRAM Pusat yang lebih berpengalaman sebagai penyampai jemputan untuk berkongsi ilmu dan pengalaman mengenai perjuangan dakwah dan tarbiah di universiti, cabaran dan solusi yang boleh dijadikan sebagai panduan.

\section{Nadwah}

Nadwah bermaksud sebuah pertemuan yang menghimpunkan sejumlah orang yang pakar sesuatu bidang untuk mengkaji sesuatu tema ataupun persoalan secara ilmiah. Mereka akan memberikan pendapat masing-masing berdasarkan hujah dan bukti yang tepat. ${ }^{109}$

Program nadwah dilaksanakan dengan jumlah hadirin yang lebih kecil dari mu'tamar. Kebiasaannya program nadwah melibatkan beberapa kumpulan usrah untuk bersama-sama membincangkan sesuatu tajuk atau tema yang telah ditetapkan oleh pemimpin nadwah. Dalam program nadwah, perbincangan yang berlaku dalam kalangan hadirin perlu dipimpin oleh ketua nadwah yang mempunyai kepakaran dalam bidang yang akan dibincangkan di dalam nadwah. Hal ini supaya dapat mengawal perbincangan secara ilmiah dan menerima maklumat yang tepat. Antara tajuk atau tema yang dibincangkan dalam program nadwah adalah mengenai persoalan keagamaan, persoalan sosial, persoalan politik, persoalan

\footnotetext{
108 Nusaibah Mohammad (Ahli Jawatankuasa Belia Harmoni Universiti Islam Antarabangsa, Gombak), dalam temubual dengan pengkaji, 27 Oktober 2018.

109 'Alī 'Abd al-Halīm Maḥmūd, Wasā'il al-Tarbiyah 'inda al-Ikhwān alMuslimin: Dirāsah Taḥlīliyyah Tārīkhiyah, 256.
} 
ekonomi, persoalan mengenai aliran dan kefahaman yang wujud pada masa kini dan persoalan akhlak. ${ }^{110}$

Menurut Nur Zakiah Najihah, program nadwah ini adalah bertujuan untuk menguji fikrah para ahli. Beliau menyatakan lagi,

Berdasarkan pendapat saya, program nadwah ini mengajak para ahli untuk rajin berfikir dalam membincangkan apa-apa isu dan persoalan yang berkaitan dengan dakwah. ${ }^{11}$

Objektif program nadwah menurut Siti Saripa Rabiah pula adalah untuk melatih ahli menganalisis sesuatu isu dan masalah yang dibentangkan. Di samping itu, ia juga dijadikan sebagai medium untuk menyatukan fikrah para ahli agar semua ahli mempunyai kesatuan fikah. ${ }^{12}$

Menurut Aliyah pula, program nadwah ini adalah untuk memantapkan lagi bahan fikrah secara ilmiah. Beliau menambah lagi,

Bahan fikrah ini bukannya kita tidak boleh bagi di dalam usrah, tetapi ianya kerana dalam usrah itu sendiri mempunyai banyak bahan yang perlu disampaikan. Jika bahan daurah disampaikan di dalam usrah, mutarabbi kita tidak akan dapat penerangan dan kefahaman bahan tersebut secara terperinci. ${ }^{113}$

Dalam program nadwah, Illani menyatakan bahawa perbincangan yang berlaku dalam kalangan hadirin perlu dipimpin oleh ketua nadwah yang mempunyai kepakaran dalam bidang yang akan dibincangkan di dalam nadwah. Hal ini supaya dapat mengawal perbincangan secara ilmiah dan menerima maklumat yang tepat. Kebiasaannya, program nadwah ini dilaksanakan bersama-sama kumpulan-kumpulan usrah. ${ }^{114}$

Dari sudut pelaksanaan program nadwah ini pula, Nur Zakiah Najihah menyatakan bahawa program nadwah dilaksanakan

110 'Alī 'Abd al-Ḥalīm Mạ̣mūd, Wasā'il al-Tarbiyah 'inda al-Ikhwān alMuslimin: Dirāsah Taḥlīliyyah Tārīkhiyah, 307.

${ }^{111}$ Nur Zakiah Najihah Bahar (Ahli Jawatankuasa (AJK) Belia Harmoni Universiti Kebangsaan Malaysia, Bangi), dalam temubual dengan pengkaji, 26 Oktober 2018.

${ }^{112}$ Siti Saripa Rabiah Mat Lazim (Ahli Jawatankuasa (AJK) Belia Harmoni Universiti Putra Malaysia), dalam temubual dengan pengkaji, 22 Oktober 2018.

113 Aliyah Ahmad Bahari (Jawatankuasa PembangunanMahasiswa (JKPM) Universiti Islam Antarabangsa, Gombak), dalam temubual dengan pengkaji, 27 Oktober 2018.

114 Illani Zulkifli (Mantan Jawatankuasa Tarbiah Belia Harmoni Universiti Islam Antarabangsa, Gombak), dalam temubual dengan pengkaji, 22 Oktober 2018. 
sebanyak dua kali dalam setahun. Para ahli akan diberi tajuk buku yang berkaitan mengikut silibus kepada semua ahli usrah untuk dibaca. Setiap usrah perlu menghantar wakil untuk menjadi ahi panel ataupun pembentang semasa nadwah itu berlangsung. Beliau juga menyatakan,

Setiap kali program nadwah berlangsung, ia akan melibatkan beberapa kumpulan usrah. Dan setiap kumpulan usrah tersebut akan dipecahkan ahli kumpulan dan dibentuk kumpulan baru untuk sesi LDK. Sebelum perbincangan kumpulan bermula, soalan akan diberi terlebih dahulu untuk dibincangkan jawapannya bersama ahli kumpulan. ${ }^{115}$

Menurut Nusaibah pula, beliau menyatakan bahawa pelaksanaan program nadwah ini adalah mengikut keperluan ahli. Kebiasaannya, program nadwah ini dilaksanakan dalam bentuk diskusi, forum dan sebagainya. Program nadwah ini dikendalikan oleh panel-panel yang dipilih dan akan membahaskan isu-isu tertentu. Kemudian, akan diadakan sesi soal jawab antara pembentang dengan pendengar. ${ }^{116}$

Hasil kajian mendapati bahawa konsep yang dibawa dalam program nadwah ini adalah dalam bentuk bedah buku. Buku yang akan dibedah merupakan buku yang telah ditetapkan oleh JK Tarbiah IKRAM Pusat. Oleh itu, setiap usrah ditugaskan untuk melantik seorang atau dua orang wakil untuk membentangkan tajuk-tajuk dalam buku yang telah dipilih. Selesai sesi pembentangan oleh para pembentang, sesi soal jawab berlangsung untuk menjelaskan lagi kefahaman pendengar.

\section{Penutup}

Berdasarkan kepada huraian di atas, dapat dirumuskan bahawa pelaksanaan program tarbiah yang dilaksanakan oleh Belia Harmoni di Selangor dapat membantu proses pembangunan mahasiswa yang berkualiti dan seimbang dalam semua aspek. Hasil kajian ini mendapati bahawa Belia Harmoni di Selangor telah melaksanakan ketujuh-tujuh program tarbiah dalam proses

115 Nur Zakiah Najihah Bahar (Ahli Jawatankuasa (AJK) Belia Harmoni Universiti Kebangsaan Malaysia, Bangi), dalam temubual dengan pengkaji, 26 Oktober 2018.

116 Nusaibah Mohammad (Ahli Jawatankuasa Belia Harmoni Universiti Islam Antarabangsa, Gombak), dalam temubual dengan pengkaji, 27 Oktober 2018. 
pembangunan mahasiswa iaitu usrah, katibah, rehlah, mukhayyam, daurah, mu'tamar dan nadwah. Ketujuh-tujuh program tarbiah tersebut merupakan model program tarbiah yang telah dilaksanakan oleh al-Ikhwān al-Muslimūn, yang merupakan organisasi dakwah yang terkenal di seluruh dunia. Hasil kajian juga mendapati bahawa setiap program tarbiah yang dilaksanakan oleh Belia Harmoni mempunyai objektif yang jelas untuk pembangunan mahasiswa dan mempunyai bentuk pelaksanaan program yang tersusun dan fleksibel.

\section{Rujukan}

'Abd. al-Khāliq Farīd. Al-Ikhwān al-Muslimūn fì Mīzān al-Haq. Kaherah: Dār al-Ṣahwah li al-Nashr, 1987.

'Alī 'Abd al-Halīm Mạ̣mūd. Wasā'il al-Tarbiyah 'inda al-Ikhwān al-Muslimin: Dirāsah Taḥlīliyyah Tārīkhiyah. Mīdān Sayyidah Zaynab: Dār al-Tawzi` wa al-Nashr al-Islāmiyyah, 1997.

"Mukhayyam Daie Mahasiswa Kebangsaan 2019". Laman sesawang Persatuan Kebangsaan Pelajar Islam Malaysia (PKPIM), dicapai 23 Mei 2019, https://www.pkpim.org.my/2019 /05/23/mukhayyam-daie-mahasiswa-kebangsaan-2019/.

Abd. Rauf Dato' Hj. Hassan, et.al. Kamus al-Lughah alMalayuwiyyah - Al-Lughah al- 'Arabiyyah. Shah Alam: Dewan Pustaka Fajar, 2005.

Abū Fāris, Muḥammad 'Abd al-Qādir. Manhaj Taghȳ̄r 'indā alShahīdayn Hasan al-Banna wa Sayyid Quțb. Amman, Jordan: Dār Ammār, 1997.

Al-Banna, Hasan. Majmū'āh al-Rasā'il. Iskandariah: Dār al$\mathrm{Da}^{6}$ wah, 2002..

Ali Abdul Halim Mahmud, Perangkat-perangkat Tarbiah Ikhwanul Muslimin, terj. Wahid Ahmadi, Fakhruddin Nursyam dan Khozin Abu Faqih. Solo: Era Intermedia, 2009.

Al-Mu'jam al-'Arabī al-Asāsī. Cet. 1, Alesco: Larousse, 1989.

Al-Qazwīn̄̄, Ibn Fāris. Mu jam Maqāyis al-Lughah. Kaherah: Mușțafā al-Bābī al-Halabī, 1969.

Apri Rohmainy. "Tarbiah Bukan Segala-galanya," JOM!, Jun 2013, 95.

Arshad Ahmad. "Bicara IKRAM Siswa". Laman sesawang Hidup Suatu Pendakian, di capai 22 Januari 2013, https://arshadahmad .wordpress.com/2013/01/22/bicara-ikram-siswa/. 
Hawwa, Sa'īd. Fì Āfāq al-Ta'lim. Kaherah: Maktabah Wahbah, 1980.

IKRAM Siswa Nasional. "Menghitung Hari". Laman sesawang Wordpress, dicapai 5 Januari 2013, https://ikramsiswanasional .wordpress.com/2013/01/05/menghitung-hari/.

Ikram Siswa Nasional. "Pengenalan IKRAM SISWA". Laman sesawang IKRAM SISWA Nasional, dicapai 24 Disember 2013, https://ikramsiswanasional.wordpress.com/2012/12/24/pelancar an-ikram-siswa/

Kamus Dewan Edisi Ke-3. Kuala Lumpur: Dewan Bahasa dan Pustaka, 2002.

Kamus Dewan Edisi Ketiga. Cet. ke-3, Kuala Lumpur: Dewan Bahasa dan Pustaka, 1994.

Kamus Dewan Edisi Ketiga. Cet. ke-4, Kuala Lumpur: Dewan Bahasa dan Pustaka, 2002.

Maḥmūd 'Abd al-Halīm. Al-Ikhwān al-Muslimūn - Ahdāth Șana'at al-Tārīkh Ru'yatun Min al-Dākhīl. Kaherah: Dār al-Da'wah, 2004.

Mạ̣mūd, 'Alī 'Abd al-Ḥalīm. Rukn al- 'Amal Aw Manhaj al-Islāh al-Islāmī li al-Fard wa al-Mujtama'. T.tp.: Dār al-Tawzī' wa alNashr al-Islāmiyyah, 1994.

Nur Aisyah Zainordin. "Tarbiah Itu Seharusnya Menggerakkan!" JOM!, April 2012, 43.

Pejabat Pendaftar Pertubuhan Belia. "Kunjungan Hormat Barisan Kepimpinan Baru Persatuan Belia Harmoni Malaysia". Laman sesawang Laman Web Rasmi Pejabat Pendaftar Pertubuhan Belia, Kementerian Belia dan Sukan Malaysia, dicapai 7 Mac 2019, http://roy.kbs.gov.my/en/berita/kunjung-hormat-jci-malay sia-ke-atas-pejabat-pendaftar-pertubuhan-belia-malaysia-61.

Persatuan Belia Harmoni Malaysia. "Pendaftaran Persatuan Belia Harmoni Malaysia di Bawah Pendaftar Pertubuhan Belia (ROY)". Laman sesawang Facebook, dicapai 4 Mac 2019, https://ms-my.facebook.com/beliaharmonimalaysia/posts/12627 39743893585.

Pertubuhan IKRAM Malaysia. "HARMONI '16: Membumikan Gagasan Kampus Harmoni dalam Perjuangan”. Laman sesawang Pertubuhan IKRAM Malaysia, dicapai 21 Disember 2016, http:// ikram.org.my/berita/item/3097-harmoni-16-membumikan-gagas an-kampus-harmoni-dalam-perjuangan.html. 
Pertubuhan IKRAM Malaysia. "Pelancaran IKRAM Siswa Bawa Sinar Buat Generasi Baru". Laman sesawang Pertubuhan IKRAM Malaysia, dicapai 16 Januari 2013, http://www.ikram .org.my/berita/item/798-pelancaran-ikram-siswa-bawa-sinar-bu at-generasi-baru.html

Pertubuhan IKRAM Malaysia. "Reformasi IPT: Belia Harmoni Sedia Bekerjasama". Laman sesawang Pertubuhan IKRAM Malaysia, dicapai 29 Oktober 2018, http://www.ikram.org.my /berita/item/3569-reformasi-ipt-belia-harmoni-sediabekerjasama.html.

Sidek Mohd Noah. Reka Bentuk Penyelidikan: Falsafah, Teori dan Praktis. Selangor: Universiti Putra Malaysia, 2002.

Suzianah Jiffar. "Tingkatkan Ilmu Akademik, Kemahiran di Universiti". Laman sesawang Berita Harian, dicapai 29 Ogos 2019, https://www.bharian.com.my/berita/pendidikan/2019/08 /601375/tingkatkan-ilmu-akademik-kemahiran-di-universiti.

Ummu Hamzah, "Tarbiah Berteraskan Matlamat," JOM!, September 2012, 43.

Ummu Hamzah. "Apa yang Kamu Mahu daripada Tarbiah?", JOM!, Jun 2012, 67. 